\title{
New species of Neogene radiolarians from the Southern Ocean - part IV
}

\author{
Johan Renaudie* \& David B. Lazarus \\ Museum für Naturkunde, Leibniz-Institut für Evolutions- und Biodiversitätsforschung an der Humboldt-Universität zu \\ Berlin, Invalidenstraße 43, 10115 Berlin, Germany \\ *Correspondence: johan.renaudie@mfn-berlin.de
}

\begin{abstract}
In this last paper in our planned series, we describe 25 new radiolarian species from the Antarctic Neogene: 6 spumellarians (Lithatractus? floridus, Spongopylidium? aerostatum, Haeckeliella hederacia, Larcopyle faustae, Excentrodiscus planangulus and E. lappaceus) and 19 nassellarians (Anthocyrtidium sp., Artostrobus? oganeae, Botryostrobus exstructus, Ceratospyris clarki, Cornutella burgundiensis, Cystophormis petrushevskayae, Dendrospyris quadripes, Enneaphormis tippula, Euscenarium funakawai, Lophophaena kamikurii, L. rhopalica, Lychnocanium andreae, Periarachnium pauliani, Peridium tortonianicum, Phormacantha garbela, Phormospyris punnulis, Rhodospyris? morleyi, Rhodospyris pulchra and Tholospyris tautessares). We also report the finding of fragments of an unknown Middle Miocene phaeodarian (Conchellium? sp.).
\end{abstract}

Supplementary Material: List of species of polycystine Radiolarians and of Phaeodarians encountered during our study of the Antarctic Neogene is available at http://www.geolsoc.org.uk/SUP18854

Keywords: Radiolaria; Polycystinea; Phaeodarea; Antarctic; Cenozoic; taxonomy

Received 18 October 2014; accepted 20 January 2015

Neogene radiolarians are generally abundant and well preserved in Antarctic sediments, which have been recovered by both piston coring and by the various phases of the deep-sea drilling programmes. Early studies of the radiolarian assemblages concentrated either on describing the more common species of the Recent faunas for use in Quaternary palaeoceanographic research, or on identifying a small number of species in older sediments which could be used for biostratigraphy. The majority of the species present in these sediments, if not common or clearly useful for biostratigraphic zonation remained undescribed. In order to better use these faunas in studies of biodiversity dynamics (Renaudie \& Lazarus 2013b) we have carried out a fuller description of the faunas, including many of the rarer forms that typically make up a large fraction of total species richness. Many of the species encountered were new to science. In this article, the last of a series of four publications, we describe these new forms. In our three prior papers (Renaudie \& Lazarus $2012,2013 a, 2015)$ we described a total of 70 new species, to which we add 25 more in this paper. Although a very substantial number, our studies do not fully exhaust the diversity of taxa found in Antarctic Neogene sediments. There remain many only partially resolved species clusters, or groups with difficult morphologies (e.g. Actinommidae, Litheliidae) whose diversity remains to be fully diagnosed.

\section{Material and methods}

All studied samples (c. 350) come from DSDP and ODP deep-sea drilling sections from the Southern Ocean, mostly from the Kerguelen-Heard Plateau in the Indian sector of the Southern Ocean (Leg 119 Sites 737, 738, 744, 745 and 746; Leg 120 Sites 747, 748 and 751; Leg 183 Site 1138) with the addition of samples from the Atlantic sector (Leg 113 Sites 689, 690 and 693) and from the Pacific sector (Leg 29 Site 278) (Fig. 1). Prepared slides were drawn from the junior author's collection or the MRC (Micropaleontological
Reference Center) radiolarian collection hosted by the Museum für Naturkunde in Berlin (Lazarus 2006). Samples were prepared to random strewn slides using standard methods (Moore 1973) using either 38,45 or $63 \mu \mathrm{m}$ sieves.

The radiolarian biozonation follows Lazarus (1992) and Abelmann (1992). The age estimates used for the range chart (Fig. 2) are inferred linearly from an age model based on Gersonde et al. (1990) for Leg 113, Barron et al. (1991) for Leg 119, Harwood et al. (1992) for Leg 120 and Bohaty et al. (2003) for Leg 183, with all ages adjusted to the Berggren et al. (1995) time-scale. The relative abundances given in the range chart are drawn from counts made on $45 \mu \mathrm{m}$ strewn slides for 119 of the c. 350 samples. Measurements were made on specimen pictures using ImageJ (Abramoff et al. 2004): the range of variation and the mean (between brackets) are both given in microns $(\mu \mathrm{m})$ under the Dimensions section for each species.

Higher-level classification largely follows that of Riedel (1967), with a few subsequent emendations as individually noted below.

The terminology used here follows mostly Jørgensen (1905) and Petrushevskaya $(1965,1968)$ for nassellarian internal structure (Fig. 3), Goll (1968) for features specific to the family Trissocyclidae and Boltovskoy (1998) for general external characters. The notation for connecting arches in nassellarians follows generally De Wever et al. (1979), Dumitrica (1991) and Funakawa $(1995 a)$ in which they are named after a combination of the initials of the spines they originate from (i.e. arch $\mathbf{A V}$ would be an arch connecting spine A and spine V, see Fig. 3a), or, when necessary, follows Petrushevskaya $(1965,1968)$ in which they are named after the apophyses they are joining (i.e. arche mj joins apophyses $\mathrm{m}$ on spine $\mathbf{A}$ and $\mathrm{j}$ on spine $\mathbf{V}$, see Fig. 3b).

All holotypes are deposited in the micropaleontology collection of the Museum für Naturkunde, Berlin and are indentified by their accession numbers (ECO-xxx) in the descriptions. Specimens are identified by a circle on the slide. 


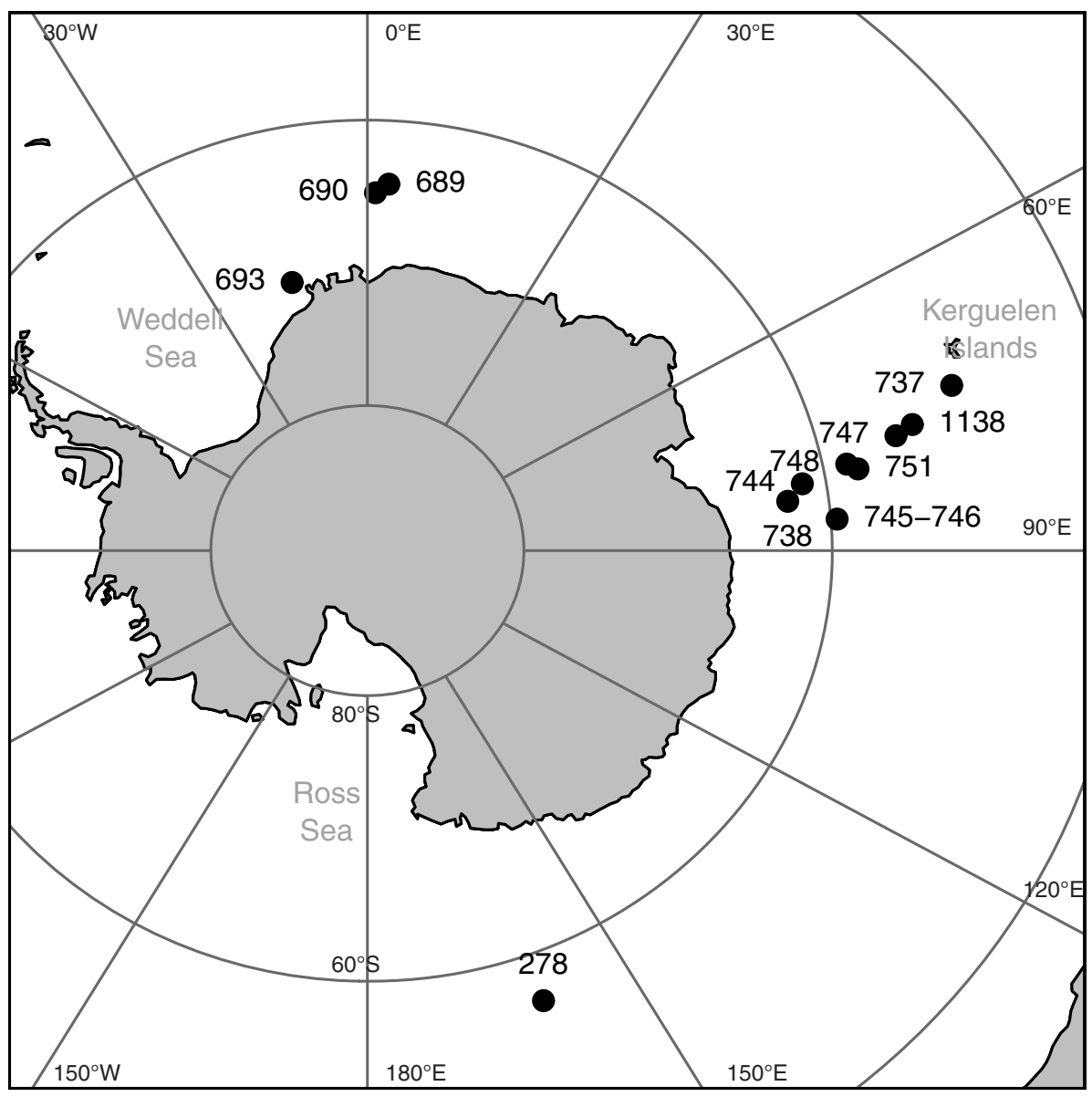

Fig. 1. Location of studied sites. Map created using $\mathrm{R}$ with package GEOmap (Lees 2010).

\section{Systematic palaeontology}

Phylum Rhizaria Cavalier-Smith, 2002

Class Cercozoa Cavalier-Smith, 1998, emend. Adl et al., 2005

Subclass Phaeodarea Haeckel, 1879

Family Conchariidae Haeckel, 1879

Genus Conchellium Haeckel, 1887

Type species. Conchellium tridaena Haeckel, 1887

Conchellium? sp.

(P1. 1, figs 7A-8)

Material. Ten fragments observed in ODP Sites 689, 690 and 751.

Occurrence. Sporadic from the Actinomma golownini Zone to the Acrosphaera australis Zone (Middle to Late Miocene).

Remarks. The fragments found are those of a hemispherical shell of c. $150-200 \mu \mathrm{m}$ diameter. It bears numerous, small, perfectly round, tube-like pores whose external rims extend laterally to form a second shell layer, seemingly (P1. 1, fig. 7B), evoking what can be seen in Acrosphaera australis Lazarus, 1990. All these pores are arranged in quincuncial rows. The brownish tint of the shell indicates that it is probably a phaeodarian.

Specimen in Plate 1, figure 7A-B is the most complete fragment found to date.

The only other Conchariidae we recognized in the Neogene fossil record of the Southern Ocean is ?Conchellium capsula Borgert, 1907, which differs quite clearly from these fragments in its large polygonal pores.

Class Radiolaria Müller, 1858

Superorder Polycystinea Ehrenberg, 1839 emend. Riedel, 1967
Order Spumellaria Ehrenberg, 1876

Family Actinommidae Haeckel, 1862 emend. Sanfilippo \& Riedel, 1980

Genus Lithatractus Haeckel, 1887

Type species. Stylosphaera fragilis Haeckel, 1887

Lithatractus? floridus $\mathrm{n} . \mathrm{sp}$

(Pl. 1, figs 1A-3)

Derivation of name. From the Latin adjective floridus meaning 'flowering', for the flower-shape pore arrangement.

Diagnosis. Unequal polar spines, pores arranged in flower-shaped packs of seven, themselves arranged in a hexagonally-packed pattern.

Holotype. Plate 1, figure 2A-B; sample 119-744A-8H-3, $53-55 \mathrm{~cm}$ (Early Miocene); ECO-083.

Material. 97 specimens from DSDP Site 278 and ODP Site 744.

Description. Ellipsoidal shell with two polar spines: one long (more than the length of the shell) and tribladed, the other short, triangular and tribladed at its base. Pores on the shell are small and round, closely packed, arranged by group of seven in a petaloid pattern. This pattern is repeated and itself arranged in a hexagonal pattern. There is $c$. 6 of such petaloid groups of pores in a halfequator. Bars between the pores seem (based on observation of half-dissolved specimens, see Pl. 1, fig. 3) to be thinner between the pores of one such group and thicker between each group of pores. Both types of bars are very narrow. No medullary shell was observed to date. 


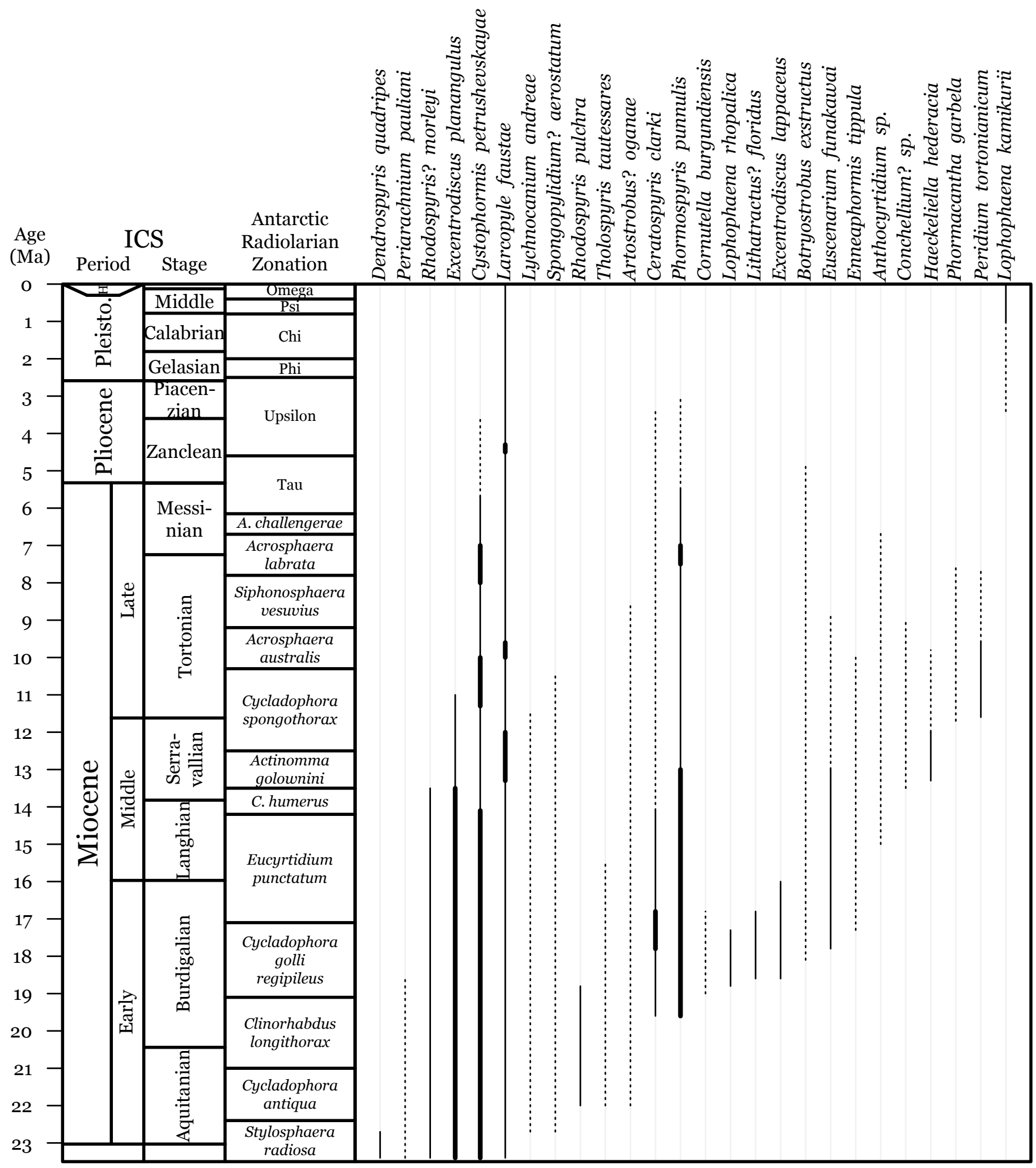

Fig. 2. Range chart of the species described herein. Antarctic radiolarian zonation follows Abelmann (1992) and Lazarus (1992). Numerical age of zonal boundaries after Spencer-Cervato (1999). Width of bars corresponds to a rough estimate of the species abundance: dashed line is 'sporadic', plain line 'rare' $(<0.5 \%$ of the assemblages) and bold line 'common' $(>0.5 \%)$. A. challengerae, Amphymenium challengerae; C. humerus, Cycladophora humerus; Pleisto., Pleistocene; H, Holocene.

Dimensions. Based on 3 specimens. Length of cortical shell main axis: 77-86 (83); of cortical shell minor axis: 70-79 (74); of long spine: 88-97 (94); of short spine: 16-21 (19).

Occurrence. Rare to common in the Cycladophora golli regipileus Zone (Early Miocene).

Remarks. Lithatractus? floridus n. sp. is significantly smaller, has a smaller number of relatively large main pores on the cortical shell, and has a noticeably thinner cortical shell in comparison to Sphaerostylus rosetta Blueford, 1982, Stylatractus neptunus Haeckel, 1887, or any of the several 'stylosphaerid' species of Ehrenberg, as illustrated in Suzuki et al. (2009b) and Ogane et al. (2009). The overall outline of this species is very similar to that of Lithatractus timmsi Campbell \& Clark, 1944 (and, to some extent, to that of the more robust form Stauroxiphos communis Carnevale, 1908) but it differs from it in possessing only one small spine instead 
(a)

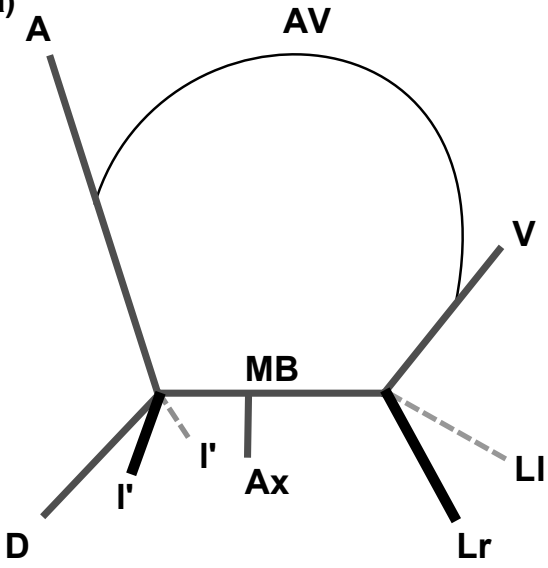

(b)

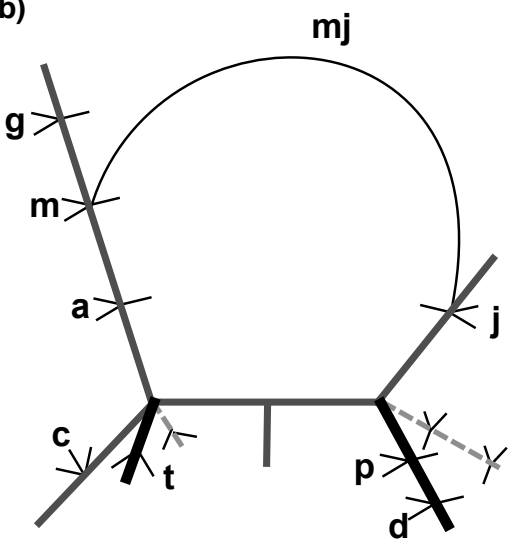

Fig. 3. Schematic illustrations of nassellarian cephalic inner structure. (a) Initial Spicule (modified after Jørgensen 1905). A, apical spine; $\mathbf{V}$, ventral or vertical spine; $\mathbf{D}$, dorsal spine; $\mathbf{L r}$ and $\mathbf{L l}$, left and right primary lateral spines; I', secondary lateral spine; $\mathbf{M B}$, median bar; $\mathbf{A x}$, axobate; $\mathbf{A V}$, arch connecting spine $\mathbf{A}$ and spine $\mathbf{V}$. Dark grey, spines in the sagittal plane (i.e. the plane of $\mathbf{A}$, MB, D and V); black, spines on viewer side of the sagittal plane; light grey, spines on the other side of the sagittal plane. (b) Apophyses (modified after Petrushevskaya 1971). g, galear; m, mitral; a, anterior; t, tergal; c, cervical; $\mathrm{p}$, pectoral; j, jugal; d, second series of apophyses on spines $\mathbf{L I}$ and $\mathbf{L r}$; $\mathbf{m j}$, arch connecting apophyses $\mathrm{m}$ and $\mathrm{j}$. of several small spines on the opposite pole of the large spine and in its peculiar pore arrangement. It differs in general from most other stylosphaerids because of its 7-fold petaloid subpore arrangement, but in addition to that it also differs from Druppatractus irregularis Popofsky, 1912 and D. nanus Blueford, 1982 in having one long spine (at least longer than the cortical shell) and from Druppatractus hastatus Blueford, 1982 in the latter having a flattened cortical shell. Species of the genus Druppatractus also have a pyriform medullary shell but no medullary shell was observed in Lithatractus? floridus n. sp. to date. As this absence is likely to be purely taphonomical, the generic assignment is based only on overall similarity of the cortical shell shape and is therefore only tentative.

Genus Spongopylidium Dreyer, 1889 emend. Suzuki et al., 2009 a

Type species. Spongopyle (Spongopylidium) ovata Dreyer, 1889.

Spongopylidium? aerostatum n. sp.

(Pl. 1, figs 4-6B)

Derivation of name. From the modern Latin aerostatum meaning 'hot-air balloon'.

Diagnosis. Spherical outline; narrow pylome with peristome; crested pore frame.

Holotype. Plate 1, figures 6A-B; sample 120-751A-9H-5, 98-102 cm (Late Miocene); ECO-084.

Material. 27 specimens from DSDP Site 278 and ODP Sites 744 , 748 and 751.

Description. Large spherical single cortical shell. The shell wall is latticed and bears many circular pores of similar size. The bars between the pores are thick and crested, giving the whole shell a honeycomb aspect. The pores are arranged in an irregular hexagonal pattern.

A small pylome protrudes from the shell. It is surrounded by a hyaline, narrow, fairly long and thick-walled peristome. Its termination can be smooth (see Pl. 1, fig. 4) or ragged (see Pl. 1, fig. $5 \mathrm{~B}$ ). The pore pattern around the pylome is particularly irregular. No medullary shell was observed.

Dimensions. Based on 5 specimens. Diameter of shell: 174-249 (210); width of pylome: 18-30 (26).

Occurrence. Sporadic from the Cycladophora antiqua Zone to the Cycladophora spongothorax Zone (Early to Late Miocene).

Remarks. The complete lack of medullary shell in S.? aerostatum n. sp. may very well be taphonomical. All comparisons can therefore be based only on the elements of the cortical shell (which hinders proper assignment to a genus), however, S.? aerostatum does seem to show a unique combination of these elements.

Lithocarpium monikae Petrushevskaya, 1975 differs from this species in having an elliptical instead of a circular outline, in its thinner cortical shell having tinier, more numerous pores arranged randomly in a $3 \mathrm{D}$ meshwork and in having a spongy medullary shell linked to the cortical shell by relatively thick radial beams; even if the absence of medullary shell in our species is likely to be taphonomical, the junction of the radial beams with the cortical shell could have been seen. Prunopyle frakesi Chen, 1975 has a narrow pylome but it is surrounded by a cluster of spines instead of being prolonged by a peristome; additionally the pores in this species are more numerous, smaller, more closely packed and, more importantly, tube-shaped. Finally the shell wall of $P$. frakesi is smooth and its shell outline elliptical. Enamelon inemmestrum Sugiyama, 1992 shares with S.? aerostatum many characteristics: its spherical shell outline and its narrow pylome with a fairly long hyaline peristome. However, they differ in their shell wall which is, in E. inemmestrum, smooth and covered by a multitude of small pores. The size range of the last two species is also considerably larger than that of $S$.? aerostatum (270 to $342 \mu \mathrm{m}$ for $P$. frakes $i$ and 290 to 430 for E. inemmestrum). The Paleocene specimen illustrated in Nishimura (1992, pl. 11, fig. 10) as Diploplegma (?) sp. aff. D. somphum Sanfilippo \& Riedel, 1973 is also very similar to $S$ ? aerostatum for the same reasons invoked in the comparison with E. inemmestrum but they differ in that Nishimura's specimen possesses a thick spongy outer layer over the cortical shell. Larcopyle titan (Campbell \& Clark, 1944) differs from S.? aerostatum in its larger pylome, its elliptical outline, its shell thickness and in having smaller, irregular pores with at most only weak frames. L. titan also possesses internal shell structures, although these are very delicate and difficult to visualize.

Sphaeropyle langii Dreyer, 1889, S. antarctica (Dreyer, 1889), S. tetrapila (Hays, 1965) and S. robusta Kling, 1973 all differ from this new species in the shape of their pylome: in all these species, the pylome is wide and surrounded by several spines, whereas in $S$.? aerostatum it is narrow and prolonged by a hyaline peristome.

Finally, Spongopylidium pyloma (Reynolds, 1980) is a species apparently devoid of medullary shell, having a thick latticed wall and a pylome very similar to that of S.? aerostatum. However, it differs from $S$ ? aerostatum in its small size, elliptical outline, the smoothness of its cortical shell and the random arrangement of the pores. We tentatively assign our new species to the genus Spongopylidium because of the similarity between the pylome of S. pyloma and the one of $S$.? aerostatum coupled with the apparent absence, in both forms, of a 


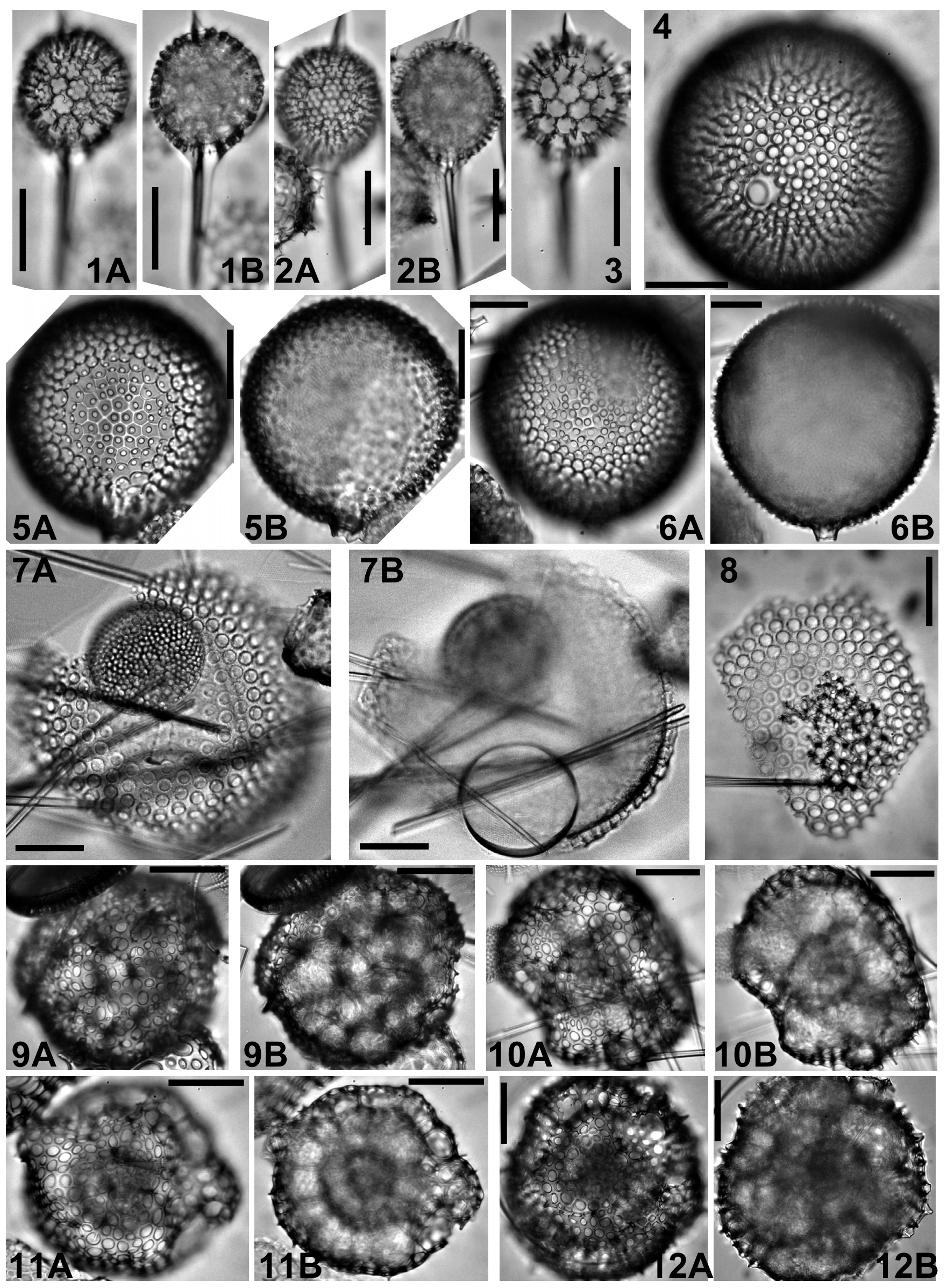


medullary shell. Enamelon inemmestrum also shared a similar pylome but its dense spongiose inner shell makes it stand out compared to those two prior forms. Suzuki et al. (2009a) in their emendation of the genus Spongopylidium state that this genus includes forms with a spongy inner structure as well, meaning that E. inemmestrum may very well belong to that genus. It is interesting to note here that the three forms also happen to be more or less contemporaneous.

Genus Haeckeliella Hollande \& Enjumet, 1960

Type species. Haliomma macrodoras Haeckel, 1887

$$
\text { Haeckeliella hederacia } \mathrm{n} . \mathrm{sp} \text {. }
$$$$
\text { (P1. 3, figs 1A-3B) }
$$

Derivation of name. From the Latin adjective hederacius (literally 'of ivy'), after the trellis-like lattice climbing over the spines of this species, as ivy on a tree.

Diagnosis. Smooth, single layer cortical shell with large spines surrounded by a secondary wiring, regularly connected to them.

Holotype. Plate 3, figure 1A-B; sample 113-690B-6H-4, 22$24 \mathrm{~cm}$ (Early Miocene); ECO-082.

Material. 48 specimens, including fragments of spines, observed in DSDP Site 278 and ODP Sites 689, 690, 747, 758 and 751.

Description. Large single-shelled skeleton. The cortical shell bears numerous large, irregularly-shaped (mostly elliptical or circular) pores. The bars between the pores are narrow and smooth. They do, however, exhibit some thorns now and then (see Pl. 3, figs $1 \mathrm{~B}$ and $3 \mathrm{~A}-\mathrm{B}$ ) but not at bar nodes. Some of the thorns are oriented toward the pores and not toward the exterior. The cortical shell also bears a few (6-10?) main radial spines. These spines are long and tribladed. They are attached to the cortical shell in a complex way: arches connect the blades of the spine to the bars of the cortical shell a few micrometres above the surface and again a few micrometres below the surface. The specimen on Plate 3, figure $3 \mathrm{~A}-\mathrm{B}$ shows that these spines continue inside the cortical shell as thin rods directed toward the shell centre. Unfortunately no specimen seems to have these rods or beams completely preserved and hence no medullary shell or spicule has been observed to date. At regular intervals along the spines, apophyses protrude from each blade, extend perpendicularly to the spine axis and then branch out and join one another to form eventually a secondary trellis-like lattice surrounding the spines. The bars that constitute this meshwork are very thin and cylindrical.

Dimensions. Based on two complete specimens. Diameter of shell: 271-276; diameter of pores: 4-32 (18).

Occurrence. Rare in the Actinomma golownini Zone (Middle Miocene), although some specimens were observed sporadically from the Cycladophora golli regipileus Zone to the Cycladophora spongothorax Zone (Early to Late Miocene).

Remarks. The attachment of the spines to the cortical shell seems identical to the one described for Haeckeliella macrodoras (Haeckel,
1881) in Hollande \& Enjumet (1960) and in Blueford (1982); however, the latter lacks the trellis surrounding the spines and has a large robust medullary shell. The trellis surrounding the main spines evokes what can be seen in Cleveiplegma boreale (Cleve, 1900) in Dumitrica (2013); however, the latter has a completely different cortical shell and its spines are considerably more delicate.

The assignment of this species to Haeckeliella is questionable because the inner structure is unknown.

\section{Family Heliodiscidae Haeckel, 1881}

Genus Excentrodiscus Hollande \& Enjumet, 1960

Type species. Excentrodiscus echinatus Hollande \& Enjumet, 1960

Excentrodiscus planangulus $\mathrm{n}$. sp.

(Pl. 2, figs 1A-3, 5A-6)

?1978 Excentrodiscus sp. Dumitrica: pl. 4, figs 5-6.

?1990 Actinomma medusa Abelmann: pl. 1, fig. 6.

Derivation of name. From the contraction of the Latin adjective planus (flat) and the noun angulus (corner), for this species' somewhat flattened areas.

Diagnosis. Eccentric inner microsphere, spherical to ovoid outer medullary shell, globular, somewhat flattened in spots, thin cortical shell.

Holotype. Plate 2, figure 1A-B; sample 119-744A-7H-3, 53-55 cm (Middle Miocene); ECO-075 (circle 2).

Material. 1548 specimens encountered in DSDP Site 278 and ODP Sites 744, 748, 751 and 1138.

Description. Three-shelled spumellarian with two medullary shells and one cortical shell. The cortical shell is subspherical to globular, with most specimens having at least a couple of somewhat flattened areas. The shell wall is rather thin yet bars are crested, often with raised apices that can be, rarely, expressed as small thorns. Pore size varies but they are generally medium-sized, closely packed, arranged in an irregular hexagonal pattern. Pores are generally elliptical. The outer medullary shell size varies between half and a third of the size of the cortical shell. Its shape is spherical to ovoid (with the elongated part where the inner medullary shell is situated). The shell wall is thicker than that of the cortical shell. Circular to elliptical pores are closely packed on the shell wall, but the pore diameter to bar width ratio is smaller than that of the cortical shell. Pores covering the side where the inner medullary shell lies are smaller than the others. The microsphere (i.e. inner medullary shell) is small, spherical and closely fixed to one pole of the outer medullary shell by a few robust radial beams. No beams connecting the microsphere with the distal half of the outer medullary shell were observed (see Pl. 2, fig. 3). The outer medullary shell and the cortical shell are connected by many thin, cylindrical radial beams. They do not protrude outside the cortical shell wall. The connections to the cortical shell wall tend to create characteristic small flattened areas or even depressions on the shell outline. The radial beams also seem to widen near the connection.

Explanation of Plate 1. figs 1, 2, 3. Lithatractus? floridus n. sp.: 1A, B, sample 119-744A-8H-3, 53-55 cm - (A) focus on shell wall, (B) focus on polar spines; 2A, B, sample 119-744A-8H-3, 53-55 cm, holotype - (A) focus on shell wall, (B) focus on polar spines; 3, sample 119-744A-8H-3, 53-55 cm - specimen partially dissolved. figs 4-6. Spongopylidium? aerostatum n. sp.: 4, sample 120-751A-13H-CC; 5A, B, sample 119-744A-7H-2, $53-55 \mathrm{~cm}-$ (A) focus on cortical shell, (B) focus on pylome; 6A, B, sample 120-751A-9H-5, 98-102 cm, holotype - (A) focus on cortical shell, (B) focus on pylome. figs 7, 8. Conchellium? sp.: 7A, B, sample 120-751A-12H-3, 98-102 cm, fragment - (A) focus on cortical shell, (B) focus on pores; 8, sample 120-751A-12H-6, 98-102 cm, shell fragment. figs 9-12. Larcopyle faustae n. sp.: 9A, B, sample 119-746A-14X-1, 53-55 cm - (A) focus on cortical shell, (B) focus on medullary shell; 10A, B, sample 120-751A-6H-3, 98-102 cm - (A) focus on cortical shell, (B) focus on medullary shell; 11A, B, sample 120-751A-6H-1, 98-102 cm - (A) focus on cortical shell, (B) focus on medullary shell; 12A, B, sample 119-737A-27X-2, 53-55 cm, holotype - (A) focus on cortical shell, (B) focus on medullary shell. Scale bars represent $50 \mu \mathrm{m}$. 

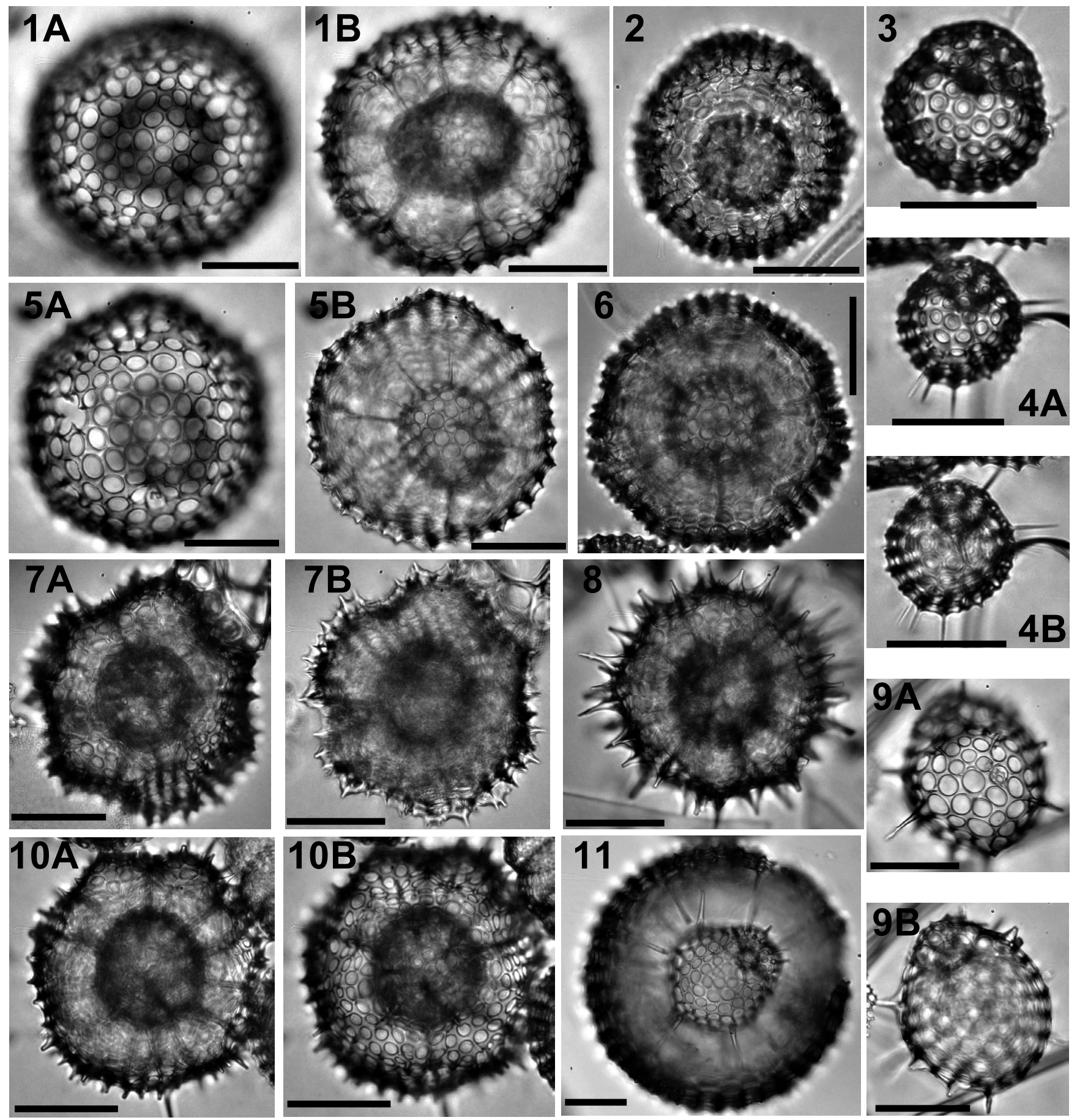

Explanation of Plate 2. figs 1-3, 5-6. Excentrodiscus planangulus n. sp.: 1A, B, sample 119-744A-7H-3, 53-55 cm, holotype - (A) focus on cortical shell, (b) focus on medullary shell; $\mathbf{2}$, sample 119-744A-7H-2, 53-55 cm; 3, sample 120-751A-13H-2, 98-102 cm - isolated medullary shell; 5A, B, sample 119-744A-8H-1, 60-62 cm - (A) focus on cortical shell, (B) focus on medullary shell; 6, sample 119-744A-7H-2, 53-55 cm. figs 4, 7, 8, 10 . Excentrodiscus lappaceus $\mathrm{n}$. sp.: 4A, B, sample 120-751A-13H-2, 98-102 cm - isolated medullary shell, (A) focus on outer medullary shell, (B) focus on inner medullary shell; 7A, B, sample 119-744A-8H-1, 60-62 cm, holotype - (A) focus on cortical shell, (B) focus on medullary shell; 8, sample 120-751A-17H-CC; 10A, B, sample 120-748B-6H-7, 45-47 cm - (A) focus on medullary shell, (B) focus on cortical shell. figs 9, 11. Excentrodiscus japonicus (Nakaseko \& Nishimura, 1974): 9A, B, sample 119-744A-4H-4, 53-55 cm - isolated medullary shell, (A) focus on outer medullary shell, (B) focus on inner medullary shell; 11, sample 113-689B-3H-5, 136-138 cm. Scale bars represent $50 \mu \mathrm{m}$.

Dimensions. Based on 8 specimens. Diameter of inner medullary shell: 11-24 (16); of outer medullary shell: 43-69 (57); of cortical shell: $103-157$ (128).

Occurrence. Common from the Stylosphaera radiosa to the Cycladophora humerus Zone (Late Oligocene to Middle Miocene), then rare until the lower Cycladophora spongothorax Zone (Middle Miocene).
Remarks. This species differs from Excentrosphaerella sphaeroconcha Dumitrica, 1978, E. kamchatica Vishnevskaya, 2006, E. kovalenki Vishnevskaya, 2006, E. sukhovi Vishnevskaya, 2006, E. spinulosa (Lipman, 1972) as illustrated in Suzuki et al. (2009a) and Excentrococcus annulatus Dumitrica, 1978 primarily in possessing only one cortical shell, but also in the outer medullary shell being connected to the cortical shell with many more radial beams. The microsphere is, however, very similar to theirs. It also shares 
the same microsphere structure with Excentrodiscus echinatus and Excentrodiscus japonicus (Nakaseko \& Nishimura, 1974) but differs from the former in lacking external spines and from the latter in its thin, globular cortical shell. Additionally, the species we recognize as Excentrodiscus japonicus in the Southern Ocean (see Pl. 2, figs 9A-B and 11) was observed from the upper Cycladophora spongothorax Zone (Late Miocene) to the Tau Zone (Early Pliocene), thus its range is not overlapping with that of our new species in the region.

Excentrodiscus planangulus n. sp. also differs from Excentrodiscus lappaceus $\mathrm{n}$. $\mathrm{sp}$. in its shell outline (at most globular but never angular), lack of external spines, the shape of the outer medullary shell and the size ratio between outer and inner medullary shell. The specimen illustrated as Excentrodiscus sp. in Dumitrica (1978, pl. 4, figs 5-6) might be conspecific with Excentrodiscus planangulus as it shares its shell ratio, shape of the outer and inner medullary shells, numerous radial beams and globular cortical shell; however, the cortical shell of that specimen seems thicker, with a more regular pore pattern.

\section{Excentrodiscus lappaceus n. sp.}

$$
\text { (P1. 2, figs 4A-B, 7A-8, 10) }
$$

Derivation of name. From the Latin adjective lappaceus meaning 'resembling a burr', after the many spines covering this species' cortical shell.

Diagnosis. Microsphere excentric, outer medullary shell spherical and cortical shell spinose and with an angular, often indented outline.

Holotype. Plate 2, figure 7A-B; sample 119-744A-8H-1, 60-62 cm (Early/Middle Miocene); ECO-027, circle 2.

Material. Thirteen specimens were observed in DSDP Site 278 and ODP Sites 744, 746, 748 and 751.

Description. Three-shelled spumellarian (two medullary shells and one cortical). The cortical shell has an angular, partially indented outline (more or less hexagonal on most specimens). The pores on the cortical shell are large, polygonal to circular, separated by narrow, crested bars. The outer medullary shell is spherical to globular, with smaller circular pores separated by thick bars. The microsphere (i.e. inner medullary shell) is eccentric, attached to the wall of the outer medullary shell. It is small and more or less spherical. It is also heteropolar as, on the hemisphere that is closer to the outer medullary shell, it bears some small bars joining it to the outer medullary shell wall. On the other hemisphere, one long rod (which could be homologous with the antapical beam seen in the species of the genus Pentactinosphaera; see Nakaseko et al. (1983) and Renaudie \& Lazarus (2013a); or indeed with the rod seen on the specimen illustrated as Heliodiscus sp. in De Wever et al. (2001, pl. 69, fig. 4)) seems to join the other side of the outer medullary shell (see specimens on P1. 2, figs 4A-B and 7A). Multiple rod-like, radial beams join the outer medullary shell and the cortical shell. They protrude outside the cortical shell wall as short but robust radial spines. These radial spines have a large tribladed base. They seem to be more numerous than the radial beams, meaning that some are probably by-spines, yet they are indistinguishable from the radial spines.

Dimensions. Based on two specimens. Diameter of inner medullary shell: 14-23, of outer medullary shell: 51-54; of cortical shell: $107-120$.

Occurrence. Rare from the Cycladophora golli regipileus Zone to the Eucyrtidium punctatum Zone (Early Miocene).

Remarks. As for the previous species, this species differs from Excentrosphaerella sphaeroconcha, E. kamchatica, E. kovalenki,
E. sukhovi, E. spinulosa and Excentrococcus annulatus in possessing only one cortical shell. It also differs from Excentrodiscus japonicus (see, in addition to Nakaseko \& Nishimura (1974), Kamikuri (2010) and herein in Pl. 2, figs 9 and 11) in its shell outline and the presence of external spines but also in the shape of its outer medullary shell, and from E. echinatus in the shape and length of the spines but also primarily in the cortical shell outline.

Thecosphaerella glebulenta Sanfilippo \& Riedel, 1973 shares with Excentrodiscus planangulus and E. lappaceus its shell outline; however, its inner medullary shell does not seem to be similar and, if the specimen of T. glebulenta illustrated by Jackett et al. (2008) indeed belongs to this species, it actually seems to be a regular concentric inner medullary shell and, consequently, this species is not a heliodiscid. Additionally the shell ratio is clearly different in this species.

Family Litheliidae Haeckel, 1862

Genus Larcopyle Dreyer, 1889 emend. Lazarus et al., 2005

Type species. Larcopyle buetschlii Dreyer, 1889

Larcopyle faustae n. sp.

(P1. 1, figs 9A-12B)

2005 Caltanisetta radiolarians Lazarus et al.: pl. 1, figs 1-6, non 7-9.

Derivation of name. Named after after Karoline Faust, in honour of her contributions to the study of litheliid taxonomy.

Diagnosis. Globular, lumpy cortical shell, with a spiraling medullary shell.

Holotype. Plate 1, figure 12A-B; sample 119-737A-27X-2, $53-55 \mathrm{~cm}$ (Late Miocene); ECO-085.

Material. 1669 specimens were encountered in DSDP Site 278 and ODP Sites 689, 690, 693, 737, 744, 745, 746, 747, 748, 751 and 1138

Description. Globular shell, with a roughly spherical to elliptical outline, deformed by numerous bumps. The shell wall is rather thin and covered with many, closely packed, round to elliptical pores of various sizes. The bars between the pores are smooth. The inner part of the shell seems to be a loose whorl that spirals from its centre and ends up merging with the cortical shell (relatively clear in specimens on Pl. 1, figs 10A to 12B). Each coil is linked to the next one (and eventually to the cortical shell) by several relatively thick radial rods (seen on P1. 1, figs 9B, 10B and 11B, particularly). The depressions between the cortical shell bumps seem to correspond to the connection of these radial rods (see e.g. Pl. 1, figs 9B and 11B).

Some specimens ( $\mathrm{Pl}$. 1, figs $10 \mathrm{~A}-\mathrm{B}$ and 12A-B) have numerous small needle-like thorns extending from the shell's bar nodes. No osculum or pylome was observed; there was no obvious sign of shell polarity.

Dimensions. Based on five specimens. Diameter of shell: 129-189 (145).

Occurrence. Rare throughout the whole Neogene and Quaternary, common in the Actinomma golownini Zone (Middle Miocene), the upper Cycladophora spongothorax Zone (Late Miocene) and the upper Tau Zone (early Pliocene).

Remarks. This species, while sharing many characters with Larcopyle polyacantha polyacantha (Campbell \& Clark, 1944) and L. p. amplissima Lazarus et al., 2005, such as its inner whorl and its cortical shell porosity, differs from them in its rounder shell outline, the looseness of its whorl and, most importantly, in its lumpy external shell. It differs also from Larcopyle labyrinthusa 
Lazarus et al., 2005 and in Larcopyle eccentricum Lazarus et al., 2005 primarily in lacking an osculum but also in its almost spherical outline. Larcopyle peregrinator Lazarus et al., 2005 shares its outline (though being actually rounder than L. faustae) but differs in its smooth, not lumpy, thick shell wall, with raised frames around its pores. Larcopyle buetschlii is more elliptical, does not have a lumpy cortical shell, and has a denser medullary shell surrounding a central polygonal structure.

The specimens illustrated as 'Caltanisetta radiolarians' from the Ehrenberg Collection in Lazarus et al. (2005, pl. 1, figs 1-6, non 7-9) are probably conspecific with this new species.

Finally, L. faustae differs from the Eocene Lithelius foremanae Sanfilippo \& Riedel, 1973 in its lumpy, thinner shell.

Order Nassellaria Ehrenberg, 1876

Family Artostrobiidae Riedel, 1967 emend. Foreman, 1973

Genus Botryostrobus Haeckel, 1887 emend. Nigrini, 1977

Type species. Lithostrobus botryocyrtis Haeckel, 1887

Botryostrobus exstructus $\mathrm{n}$. sp.

(Pl. 3, figs 9-12)

Derivation of name. From the Latin exstruo meaning 'to pile up, to stack', because of the impression that this species' segments are randomly stacked on top of one another.

Diagnosis. Wavy post-thoracic segments with numerous transverse pore rows; row of wider pores at the lumbar stricture.

Holotype. Plate 3, figure 12; sample 119-745B-23H-2, 53-55 cm (Late Miocene); ECO-086.

Material. Fifty-three specimens were observed in ODP Sites 693, 757, 745, 746, 747, 748, 751 and 1138.

Description. Multi-segmented nassellarian with its spherical cephalis embedded in its campanulate thorax. The cephalis bears a short, needle-like apical horn and an upward-directed ventral tube (see Pl. 3, figs 9 and 12). The thorax is separated from the postthoracic segments by a lumbar stricture expressed externally, in most specimens, by a narrower hyaline ring. All post-thoracic segments are short, of various widths, sometimes giving the shell a wavy outline. Although the last segment termination is ragged, hinting at the possibility that the shell is not complete, most specimens' last segment differs from the previous segment in being flared (see Pl. 3, figs 10-12). The pores on the cephalothorax are round and arranged in transversal rows. The last row before the lumbar constriction is usually composed of larger pores (see Pl. 3, figs 9-10, 12). The pores on the post-thoracic segments are also arranged in transversal rows, but are smaller and, in most cases, elliptical to quadrate and elongated in the direction of the rows. Some specimens have a shape gradient from circular pores to rectangular pores from their most proximal to the most distal postthoracic segment (see typically Pl. 3, fig. 9-10). The wider segment is usually the first or second post-thoracic segment.

Dimensions. Based on the four specimens figured. Total height: 118-144 (121); maximum width: 54-68 (56); height of the cephalothorax: 38-41 (39); maximum width of the cephalothorax: 4152 (45).

Occurrence. This species was encountered sporadically from the Cycladophora golli regipileus Zone (Early Miocene) to the Tau Zone (Early Pliocene).

Remarks. Because of its upward-directed ventral tube (visible in the specimens illustrated in Pl. 3, figs 9 and 12), its apical horn, its numerous segments and its transversal rows of pores, this species is clearly congeneric with other species of the genus Botryostrobus. It, however, differs from Botryostrobus bramlettei (Campbell \& Clark, 1944 ) in the outline and size of the post-thoracic segments (they are at least as long as the thorax in B. bramlettei); from Botryostrobus miralestensis (Campbell \& Clark, 1944) and from Botryostrobus acquilonaris (Bailey, 1856) in their fusiform outline and the uniform height of their post-thoracic segments; from Botryostrobus auritusaustralis (Ehrenberg) group sensu Nigrini, 1977 and Botryostrobus? sp. in Nigrini (1977, pl. 1, fig. 6) primarily in lacking a wide constriction between each post-thoracic segments. It also differs from Artostrobus? oganeae $\mathrm{n}$. sp. described herein in possessing a ventral tube, in the shape of its post-thoracic pores and in the size differentiation between the thoracic pores and the post-thoracic pores.

Family Carpocaniidae Haeckel, 1881 emend. Riedel, 1967

Genus Cystophormis Haeckel, 1887

Type species. Cystophormis pyla Haeckel, 1887

Cystophormis petrushevskayae $\mathrm{n} . \mathrm{sp}$. (pl. 4, figs 5A-6, 9-12)

1972 Carpocanistrum sp. aff. Sethocorys odysseus (Haeckel); Petrushevskaya \& Kozlova: pl. 22, fig. 16.

1975 Cystophormis brevispina (Vinassa de Regny) group; Petrushevskaya: 588; pl. 13, figs 3-7; pl. 44, figs 1-2; non Carpocanistrum brevispina Vinassa de Regny, 1900: 579-580; pl. 2, fig. 23.

1989 Cystophormis brevispina? (Vinassa de Regny); Lazarus \& Pallant: 363; pl. 5, figs 14-15.

Derivation of name. Named after Maria G. Petrushevskaya who first illustrated the species.

Diagnosis. Dicyrtid with a three-lobed cephalis separated from the thorax by a change in contour, a thorax with longitudinally-aligned pores, and a hyaline peristome.

Holotype. Plate 4, figure 9; sample 119-737B-6R-2, 54-56 cm (Middle Miocene); ECO-087.

Material. 3163 specimens were encountered in DSDP Site 278 and ODP Sites 689, 690, 737, 744, 746, 747, 748, 751 and 1138.

Description. Thick-walled, two-segmented nassellarian. The cephalis and the thorax are clearly distinguished by a change in contour. The thorax is subspherical to barrel-shaped. It bears more or less regular longitudinal rows (6-10 rows on a hemisphere) of round pores (4-6 per row). The rows, transversally, are arranged quincuncially. The bars between the pores are large, thick and crested. In most specimens, the crests appear as longitudinal wavy ridges. The thorax terminates in a hyaline peristome, often bearing ridges at its base (where the pore rows end). Externally the peristome is invertedtruncated-conical and internally cylindrical. The opening is usually narrower than the cephalis width but wider than the eucephalic lobe. The peristome ends without any teeth or ornamentation, with a smooth rim. The internal length of the peristome is roughly similar to the height of the cephalis. The cephalis is dome-shaped with three clear lobes. The antecephalic and the eucephalic lobe are separated by spine $\mathbf{A}$ which, in some rare specimens, protrudes as a small, needle-like spine. The eucephalic lobe is higher than the two others and, in many specimens, there is a change of contour between the lobes (though less abrupt than the one in Cystophormis ob Petrushevskaya, 1975). The postcephalic lobe is separated from the eucephalic lobe by a spine $\mathbf{V}$ or $\mathbf{V}^{\prime}$. Externally the cephalis is very rough, with a few, small, randomly arranged pores.

Dimensions. Based on 5 specimens. Total height: 88-99 (97); height of cephalis: 20-26 (22); of peristome: 10-18 (16); 

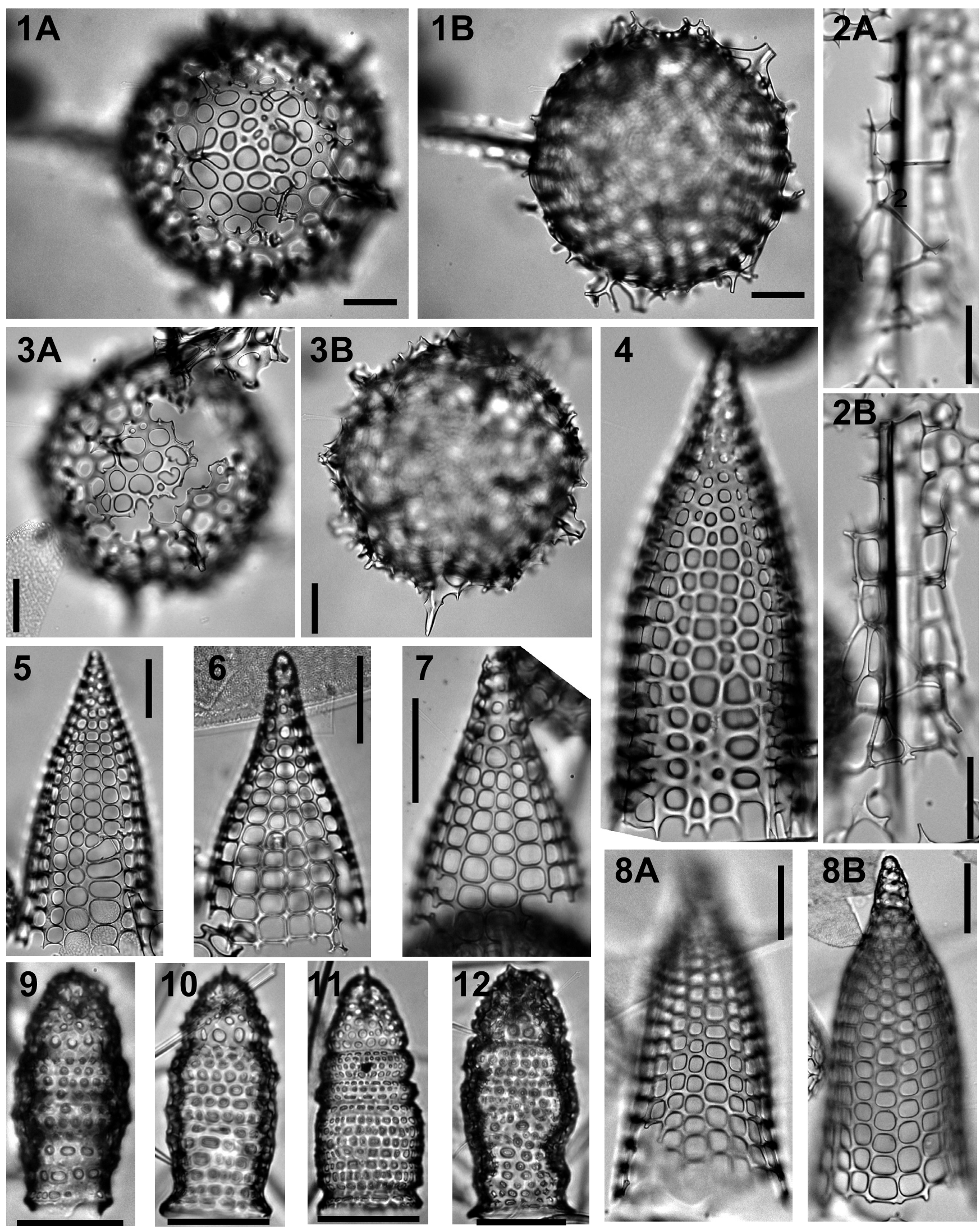

Explanation of Plate 3. figs 1-3. Haeckeliella hederacia n. sp.: 1A, B, - sample 113-690B-6H-4, 22-24 cm, holotype - (A) focus on shell surface, (B) focus on shell outline; 2A, B, sample 120-748B-6H-5, 45-47 cm - isolated spine, (A) focus on secondary wiring, (B) focus on spine; 3A, B, sample 120-748B-6H-5, 45-47 cm - (A) focus on shell surface, (B) focus on shell outline. figs 4-6, 8. Cornutella burgundiensis n. sp.: 4, sample 120-748B6H-7, 45-47 cm; 5, sample 119-744A-10H-2, 60-62 cm; 6, sample 119-744A-10H-2, 60-62 cm; 8A, B, sample 120-748B-7H-2, 45-47 cm, holotype - (A) focus on thoracic wall, (B) focus on cephalis. fig. 7. Cornutella burgundiensis?, sample 120-748B-7H-4, 45-47 cm. figs 9-12. Botryostrobus exstructus $\mathrm{n}$. sp.: 9, sample 119-745B-15H-4, 53-55 cm; 10, sample 119-745B-19H-5, 46-48 cm; 11, sample 119-745B-22H-6, 53-55 cm; 12, sample 119-745B-23H-2, 53-55 cm, holotype. Scale bars represent $50 \mu \mathrm{m}$. 
maximum width: 77-93 (84); width of cephalis at collar stricture: 47-53 (49); width of peristome (inside): 26-31 (28); width of peristome (outside): 40-57 (51).

Occurrence. Rare to common from the Stylosphaera radiosa Zone to the Amphymenium challengerae Zone (Late Oligocene to Late Miocene), then sporadic until the lower Upsilon Zone (Early Pliocene). Funakawa \& Nishi (2005) reported a first occurrence for the Cystophormis brevispina (Vinassa de Regny) group Petrushevskaya, 1975 down in the Early Oligocene (in palaeomagnetic Chron C12r).

Remarks. This species is classically found in the literature as Cystophormis brevispina (Vinassa de Regny, 1900) group Petrushevskaya, 1975; however, we do not believe this species is the one described and illustrated by Vinassa de Regny as it differs significantly from its diagnosis: it is described as possessing a multitude of tiny spines around its peristome ('Appendici basali numerose, piccolissime, simili a minute spine' (Vinassa de Regny 1900, p. 580), also shown in his drawing) which this species completely lacks. Furthermore his drawing of the species does not show any separation or shell wall differentiation between the cephalis and the thorax when this separation is very clearly marked in C. petrushevskayae.

This species shares its trilobed cephalis with Cystophormis ob Petrushevskaya, 1975 and Cystophormis gargantua Renaudie \& Lazarus, 2012 but it is easily differentiated from these two species in the former having very distinctly separated cephalic lobes, a short, thin, subspherical thorax with a few large, closely packed pores, and the latter being at least twice as large, with a large, subspherical to barrel-shaped thorax and consequently a very small cephalis to thorax size ratio. It differs from Sethocorys odysseus Haeckel, 1887 and from species of genera Carpocanium and Carpocanistrum primarily in its distinctly trilobed cephalis and the change in contour at the collar stricture. It also differs from species of the genus Plannapus O'Connor, 1997, and from Carpocanium? uburex Renaudie \& Lazarus, 2012 in the cephalic lobes being arranged in a row in the sagittal plane. It finally differs from Cystophormis pulchrum (Carnevale, 1908) - illustrated here on Plate 4, figure 14 - in the cephalis to thorax ratio which is higher in the latter, in the change in contour at the collar stricture (absent in C. pulchrum) and in the latter having a longer peristome (more than half the length of its thorax) ending in shovel-shaped teeth.

Family Theoperidae Haeckel, 1881, emend. Riedel, 1967

Genus Artostrobus Haeckel, 1887

Type species. Cornutella? annulata Bailey, 1856

Artostrobus? oganeae n. sp.

(Pl. 4, figs 1-3B)

2009a Eurystomoskevos sp. 1 Suzuki et al.: 265, pl. 22, fig. $8 \mathrm{~A}-\mathrm{B}$.

Derivation of name. Named after Kaoru Ogane for her contribution to radiolarian taxonomy.

Diagnosis. Characterized by a campanulate thorax, a clear lumbar stricture and several irregular post-thoracic segments with pores aligned transversally.

Holotype. Plate 4, figure 2A-B; sample 120-751A-12H-3, 98$102 \mathrm{~cm}$ (Middle Miocene); ECO-088.

Material. Forty specimens were observed from ODP Sites 689, 748,751 and 1138 .

Description. Multi-segmented nassellarian with a spherical cephalis separated from a long campanulate thorax by furrows along arches $\mathbf{D L}$ and $\mathbf{L L}$, and post-thoracic segments separated from the thorax by a distinct lumbar stricture. The cephalis wall bears several circular and randomly distributed pores. Spine $\mathbf{A}$ is free in the cephalic chamber but is close to the dorsal side of the wall. It protrudes subapically as a short triangular horn. Spines $\mathbf{D}, \mathbf{L} \mathbf{l}$ and $\mathbf{L r}$ protrude at the collar stricture as downward-directed, conical wings, no longer than the thorax. Arches AL are visible on the cephalic wall of some specimens. The thorax bears three to four rows of round pores aligned transversally. Pores on post-thoracic segments are usually larger and more closely packed than those of the thorax. The abdomen is usually short with only a couple of pore rows, but some specimens have longer abdomens. The postthoracic segments are usually irregularly shaped, from somewhat campanulate to annular and are not systematically aligned with one another, giving the shell a somewhat wavy outline. The last segment has a ragged termination.

Dimensions. Based on three specimens. Height of cephalis: 12-17 (15); of thorax: 24-28 (26); of abdomen: 10-34 (20); of postabdominal segments: 16-28 (22); maximum width: 48-56 (52); width of cephalis: 16-21 (19); of thorax: 36-42 (40).

Occurrence. Sporadic to rare from the Cycladophora antiqua Zone (Early Miocene) to Acrosphaera australis Zone (Late Miocene). Suzuki et al. (2009a) reported a specimen that seems to be conspecific with our new species in the Middle Eocene, although the basal segment in the Eocene form is considerably more flared than is typical for our species.

Remarks. This species was assigned to the genus Artostrobus because, just as in A. annulatus, A. joergenseni Petrushevskaya, 1971 and A. quadriporus Bjørklund, 1976, it possesses a cephalis clearly separated from the thorax, an apical horn and up to three wings and multiple post-thoracic segments with transversal rows of pores. However, in contrast with these species, it has, as does $A$.? semazen Renaudie \& Lazarus, 2012, a long campanulate thorax that accounts for at least a third of the specimen height, and a clearly expressed lumbar stricture. It differs from the latter in its shorter apical horn and in the latter having a flared abdomen and no post-abdominal segments. It differs from artostrobiids, such as Siphostichartus corona (Haeckel, 1887) or Botryostrobus auritus-australis (Ehrenberg, 1844) group Nigrini, 1977, primarily in lacking a ventral tube and in the cephalis and the thorax being clearly differentiated.

Genus Cornutella Ehrenberg, 1839

Type species. Cornutella clathrata Ehrenberg, 1839

$$
\text { Cornutella burgundiensis n. sp. }
$$$$
\text { (Pl. 3, figs 4-8B) }
$$

Derivation of name. Named after the shape of the Burgundy wine bottle (from the Latin burgundiensis meaning 'from Burgundy').

Diagnosis. Large Cornutella with a flaring upper thorax and an almost cylindrical lower thorax.

Holotype. Plate 3, figure 8A-B; sample 120-748B-7H-2, 45-47 cm (Early Miocene); ECO-030, circle 2.

Material. Eleven specimens were observed in DSDP Site 278 and ODP Sites 744 and 748 .

Description. Long shell with a basal opening. The cephalis is almost spherical and poreless. It is separated from the rest of the skeleton by a constriction and a furrow at the level of MB. Spine A is a thin columella joining $\mathbf{M B}$ to the shell wall subapically (it can be seen on specimen Pl. 3, fig. 8B for instance). It does not protrude outside as a horn. Some specimens (Pl. 3, fig. 6) show a tiny, thin downward-directed wing at the collar stricture. Other than 
these, spines $\mathbf{D}, \mathbf{L I}$ and $\mathbf{L r}$ are not visible. The uppermost thorax is also hyaline (yet it seems less smooth than the cephalis and actually looks like it bears infilled pores), and is conical with a narrow angle. It seems to be separated internally in a series of two to three narrow, transversal chambers (see Pl. 3, fig. 8B). The rest of the upper thorax flares widely. Finally the lower thorax (i.e. more than two-thirds of the shell) is almost cylindrical. Pores, in general, are large, and tend to get larger as they approach the thorax termination. They are longitudinally aligned but not transversally aligned. Their shape is almost round in the upper thorax and quadrate with rounded angles afterwards. Occasionally pore rows split in two (see Pl. 3, fig. 6) or merge (see Pl. 3, fig. 5). Thorax termination is ragged, with the bars between the pore rows appearing sometimes as teeth (see Pl. 3, fig. 4). Generally the thoracic shell wall is rather thin (Pl. 3, figs 6 and 7, for instance) but when it is thicker, the bars between the pore rows can look like ribs (see Pl. 3, fig. 4).

Dimensions. Based on four specimens. Total length: 253-323 (287); width at basal opening: 124-137 (130).

Occurrence. Rare in the Cycladophora golli regipileus Zone and the beginning of the Eucyrtidium punctatum Zone (Early Miocene).

Remarks. This species resembles Cornutella clathrata and Cornutella profunda Ehrenberg, 1854 in its simple spherical hyaline cephalis and its uppermost hyaline thorax. However, it differs from these two species in its size, its thorax outline, its lack of an apical horn and its large squarish pores. Cornutella trochus Ehrenberg, 1873 (Suzuki et al. 2009b, pl. 73) has a similarly flared shell shape but the lattice wall is a hexagonal meshwork rather than vertical rows of quadrate-rounded pores as in our species. It also differs from Plectopyramis dodecomma Haeckel, 1887 and Peripyramis circumtexta Haeckel, 1887 in its upper/lower thorax differentiation, in its thinner shell wall and in its smaller pores with rounded corners. Litharachnium tentorium Haeckel, 1862 also has a flaring upper thorax and longitudinal rows of pores splitting in half, but its lower thorax also flares widely, to end up flat instead of cylindrical.

Genus Lychnocanium Ehrenberg, 1847 emend. Nishimura, 1990

Type species. Lychnocanium falciferum Ehrenberg, 1854

Lychnocanium andreae $\mathrm{n} . \mathrm{sp}$.

(P1. 5, figs 3A-4B)

1992 Lychnocanoma sp. C Abelmann: pl. 5, figs 1-2.

Derivation of name. Named after Andrea Abelmann who first illustrated the species.

Diagnosis. No external collar constriction; thick, campanulate thorax; three inward-directed blade-like feet.

Holotype. Plate 5, figure 3; sample 120-748B-8H-3, 45-47 cm (Early Miocene); ECO-089.

Material. Six specimens were observed from ODP Sites 748 and 751.

Description. Large dicyrtid nassellarian with a spherical, hyaline cephalis and a large campanulate thorax bearing three feet. The cephalis seems to be half-sunken into the thoracic cavity (Pl. 5, fig. $4 \mathrm{~A})$. The inner spicule was not observed, which might indicate that it is either minute or more probably embedded in the cephalic wall. The apical horn is large, conical to blade-shaped, leaning toward the dorsal side; it has a large base. No pore was observed on the cephalic wall. The thoracic wall is very thick, campanulate with its maximum width in its lower half, and bears closely packed, large circular to hexagonal pores, arranged in a hexagonal pattern. The thorax terminates in a large hyaline rim, from which three feet depart. The feet are shorter than the length of the thorax and curved inwards. The feet are flat (i.e. with a rectangular cross-section) and at their base seem thicker on the inwards and outwards margin than at their centre (see Pl. 5, figs 3B and 4B); they seem also to terminate without tapering to their tip, as is common in other species of Lychnocanium.

Dimensions. (of the two specimens illustrated) Length of the shell (without the apical horn and the feet): 161-170; maximum width of the shell: 156-168; length of the feet: 95-110(103).

Occurrence. Found in the Stylosphaera radiosa Zone and the Cycladophora antiqua Zone (Early Miocene). Some specimens were observed from the Cycladophora humerus Zone to the Cycladophora spongothorax Zone (Middle Miocene). The specimen illustrated in Plate 5, figure $4 \mathrm{~A}-\mathrm{B}$, possibly reworked, was found in a sample belonging probably to the earliest Tau Zone (latest Miocene). Abelmann (1992) reported this species in the Cycladophora golli regipileus Zone (Early Miocene) of site 748.

Remarks. This species differs from Lychnocanoma amphitrite Foreman, 1973 primarily in lacking an abdomen, although the type specimen of $L$. amphitrite also has a more globular inflated thorax shape than our species. In addition, the size range of these two species does not overlap, as $L$. amphitrite is considerably larger than our new species: according to Foreman (1973), its overall length, without the horn, is between 190 and $280 \mu \mathrm{m}$, while the speciemens we measured for our new species lie between 161 and $170 \mu \mathrm{m}$. Foreman notes that very late specimens of $L$. amphitrite tend to have reduced abdomens, suggesting that our species is possibly a descendent form of the former species. It also differs from the specimen illustrated as Lychnocanoma sp. cf. L. bellum (Clark \& Campbell) in Foreman (1973) in its larger and thicker thorax bearing more numerous, more compactly arranged pores. Bekoma bidarfensis Riedel \& Sanfilippo, 1971 differs from this new species primarily in its peculiar cephalic structure, its two horns and its long neck.

Other species of Lychnocanium and Lychnocanoma, such as $L$. grande Campbell \& Clark, 1944, L. nipponicum Nakaseko, 1963 and Lychnocanoma magnacornuta Sakai, 1980 and L. parallelipes Motoyama, 1996, differ from this species in their size and in their long tribladed feet.

Genus Periarachnium Haeckel, 1881 emend. Nishimura, 1990

Type species. Periarachnium periplectum Haeckel, 1887

Periarachnium pauliani $\mathrm{n}$. sp.

(P1. 4, figs 4, 7-8, 15-17; ?Pl. 4, fig. 13)

?1975 Sethoconus sp. Chen: 462; pl. 10, fig. 5 non 6.

1978 Ceratocyrtis cf. histricosa Jørgensen in Dumitrica: pl. 6, figs $9,19$.

Derivation of name. Named after Paulian Dumitrica who first illustrated this species.

Diagnosis. Dicyrtid with small, thick cephalis covered by thorns; conical-campanulate thorax, ragged termination, thoracic subcircular, irregular pores more or less aligned longitudinally, increasing in size distally.

Holotype. Plate 4, figure 16; Sample 120-748B-6H-7, 45-47 cm (Early Miocene); ECO-090.

Material. Twenty-one specimens in DSDP Site 278 and ODP Sites 690, 744 and 748 .

Description. Dicyrtid nassellarian with a small, thick, hemispherical cephalis and a long, thin, conical thorax. Both segments are distinguished externally by a clear change in contour and a furrow following DL and VL (see Pl. 4, figs 4, 15 and 17). The cephalis is 

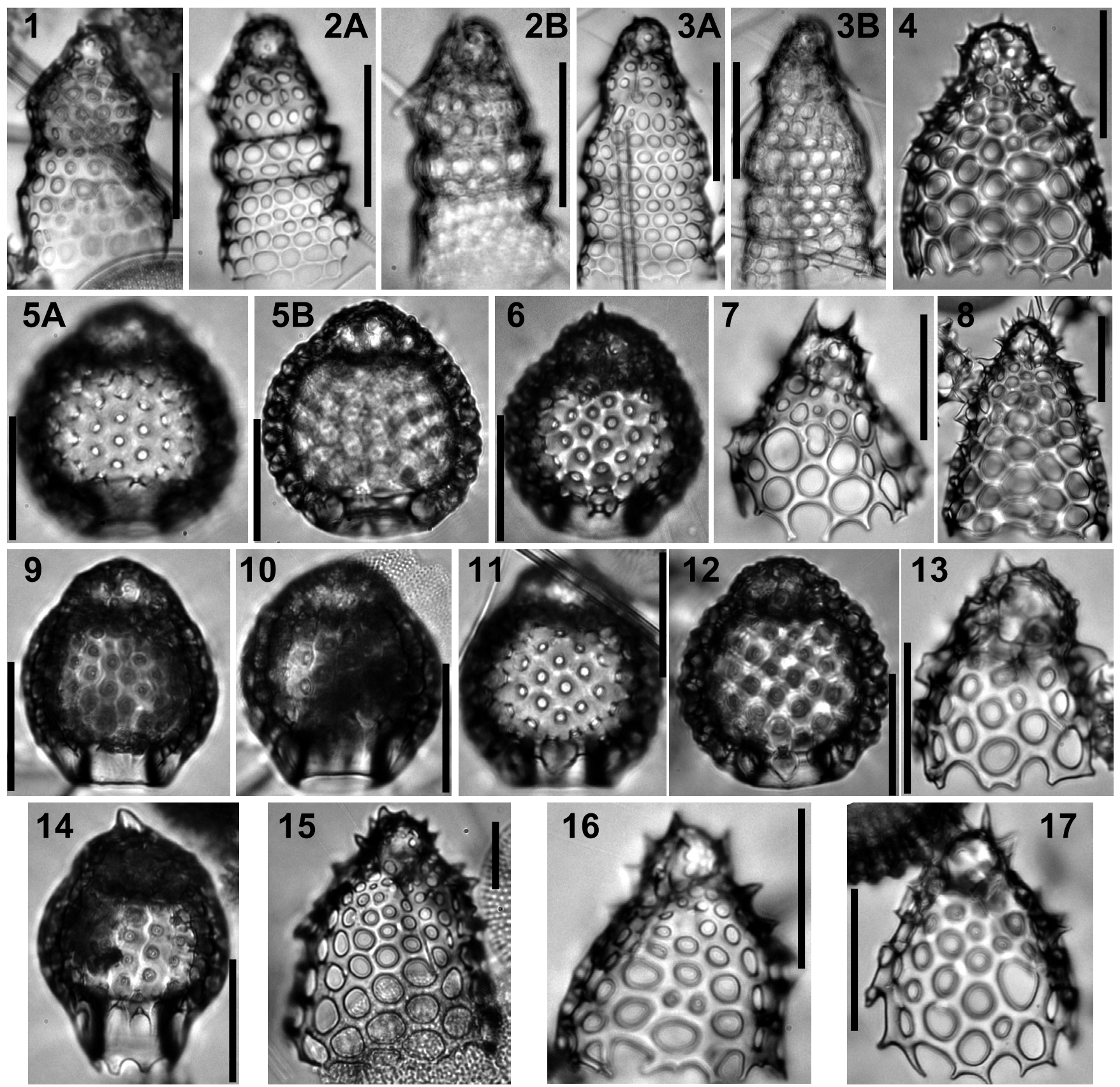

Explanation of Plate 4. figs 1-3. Artostrobus? oganeae n. sp.: 1, sample 120-751A-12H-3, 98-102 cm; 2A, B, sample 120-751A-12H-3, 98-102 cm, holotype - (A) focus on shell, (B) focus on cephalic inner structure; 3A, B, sample 120-751A-12H-3, 98-102 cm - (A) focus on shell, (B) focus on cephalic inner structure. figs 4, 7, 8, 15-17. Periarachnium pauliani $\mathrm{n}$. sp.: 4, sample 119-744A-11H-3, 60-62 cm; 7, sample 120-748B-6H-7, 45-47 cm; 8, sample 120-751A-15H-CC; 15, sample 113-690B-6H-6, 22-24 cm, 16, sample 120-748B-6H-7, 45-47 cm, holotype; 17, sample 120748B-6H-7, 45-47 cm. fig. 13. Periarachnium pauliani?, sample 120-748B-7H-6, 45-47 cm. figs 5, 6, 9-12. Cystophormis petrushevskayae n. sp.: 5A, B, sample 119-737B-5R-2, 53-55 cm - (A) focus on shell, (B) focus on cephalic inner structure; 6, sample 120-748B-6H-5, 45-47 cm; 9, sample 119737B-6R-2, 54-56 cm, holotype; 10, sample 119-737B-6R-2, 54-56 cm; 11, sample 119-737B-5R-2, 53-55 cm; 12, sample 119-737B-6R-2, 54-56 cm. fig. 14. Cystophormis pulchrum (Carnevale, 1908), sample 119-737B-6R-2, $54-56 \mathrm{~cm}$. Scale bars represent $50 \mu \mathrm{m}$.

rough and thick and bears at most one or two small, round pores (see P1. 4, figs 7 and 16). It, however, bears multiple short triangular to conical horns. The thorax is thinner than the cephalis and bears many closely packed elliptical to polygonal pores arranged, longitudinally, in rows and, transversally, quincuncially. The size of the pores increases (see Pl. 4, figs 8, 15) toward the thorax termination, which is ragged. The upper, flaring part of the thorax bears smaller pores that are more irregularly distributed and shaped, and several short, triangular to conical byspines similar to those borne by the cephalis. It also bears three ribs (see Pl. 4, figs $7,15,16)$ extending from spines $\mathbf{D}, \mathbf{L} \mathbf{l}$ and $\mathbf{L r}$ that can eventually protrude as short wings (see Pl. 4, fig. 15 and? Pl. 4, fig. 13). Spine
A seems to be free in the cephalic cavity but close to the dorsal side of the wall. It protrudes as an apical horn but is not discernable from the other additional horns. The specimen on Plate 4 , figure 8 seems to bear apophyses $m$ on $\mathbf{A}$ in the cephalic cavity close to the apex.

Dimensions. Based on eight specimens. Height of cephalis: 21-26 (23); width at collar stricture: 28-34 (32); total height: 82-139 (100); width at thorax opening: 72-102 (82).

Occurrence. Encountered sporadically from the Stylosphaera radiosa Zone (latest Oligocene) to the Cycladophora golli regipileus Zone (Early Miocene). 

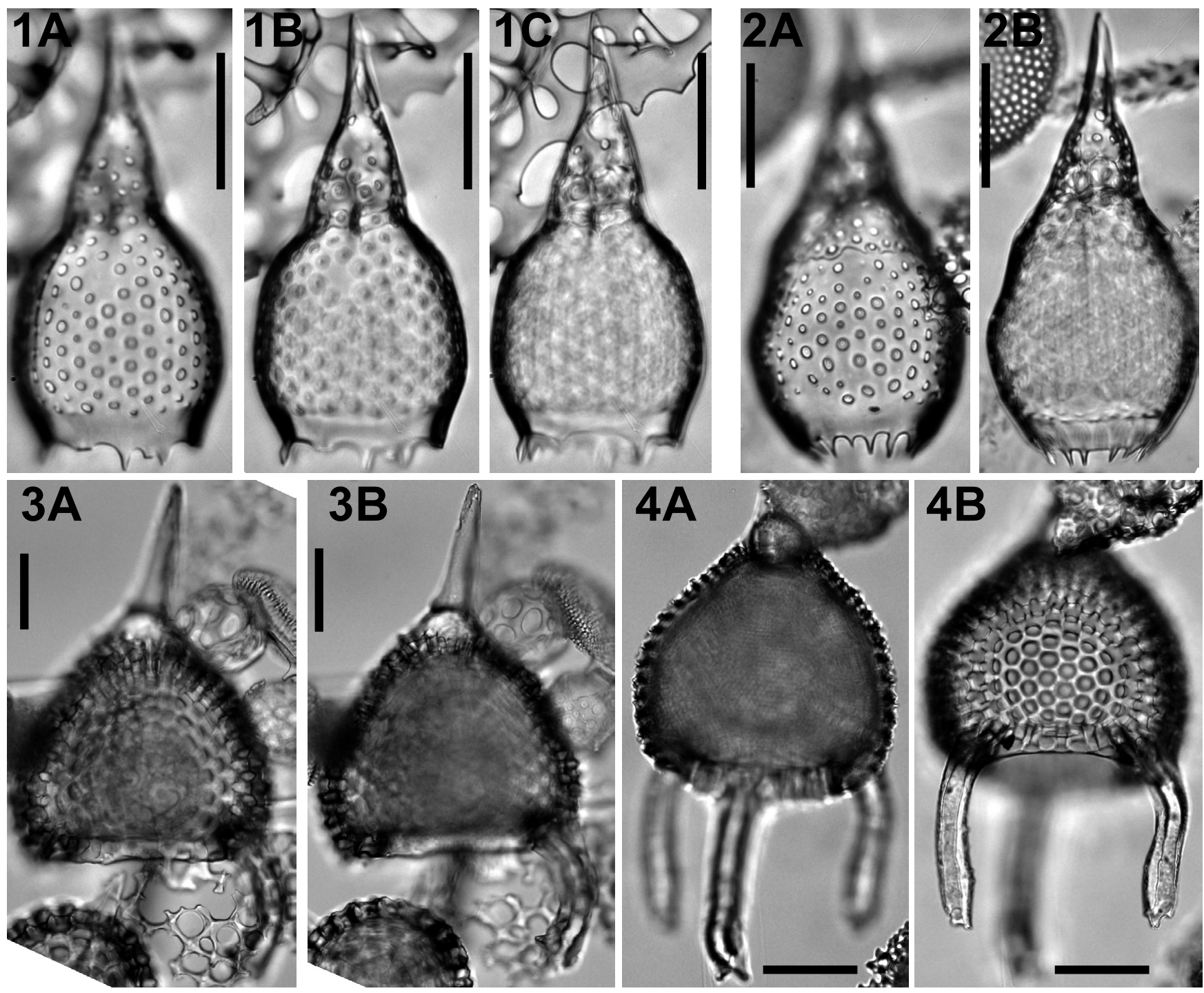

Explanation of Plate 5. figs 1, 2. Anthocyrtidium sp.: 1A-C, sample 120-751A-14H-CC - (A) focus on thoracic wall, (B) focus on cephalic wall, (C) focus on lateral lobes; 2A, B, sample 120-751A-14H-CC - (A) focus on thoracic wall, (B) focus on cephalic wall. figs 3, 4. Lychnocanium andreae n. sp.: 3A, B, sample 120-748B-8H-3, 45-47 cm, holotype - (A) focus on thoracic wall, (B) focus on cephalic wall; 4A, B, sample 120-747A-4H-3, $45-47 \mathrm{~cm}-(\mathrm{A})$ focus on cephalic wall, (B) focus on thoracic wall. Scale bars represent $50 \mu \mathrm{m}$.

Remarks. This species resembles forms like Periarachnium periplectum and P. anthocyrtis (Haeckel, 1887) in the longitudinal alignment of the thoracic pores, in the cephalis and thorax separation, in the thorns on cephalis and upper thorax, in spines $\mathbf{D}, \mathbf{L} \mathbf{l}$ and $\mathbf{L r}$ being present as ribs on the upper thorax and, according to Nishimura (1990), in sharing their cephalic structure, hence the generic assignment. It differs from them, however, in being considerably shorter, in the thickness and shortness of the cephalis and the fact that the thoracic pore size increases distally. Periarachnium pauliani $\mathrm{n}$. sp. also shares its longitudinal pore alignment and its thorns on the cephalis and upper thorax with Sethoconus tabulatus (Ehrenberg 1873) but differs in its cephalis being clearly separated by a change in contour from the thorax. It also differs from Lophocorys polyacantha Popofsky, 1913 in the wavy thorax of the latter and in the shape of the cephalis; from Phlebarachnium sp. aff. Periarachnium periplectum in Nishimura \& Yamauchi (1984) in the shape of the cephalis, the length of the thorax, the thickness of the shell and the pore diameter/ bar width ratio; from Ceratocyrtis? morawanensis Funakawa, 1995b and C.? cantharoides Sugiyama \& Furutani, 1992 in these species having well-expressed, tribladed apical and ventral horns; from Ceratocyrtis histricosus (Jørgensen, 1905) and Ceratocyrtis stoermeri Goll \& Bjørklund, 1989 primarily in their size but also in the separation between cephalis and thorax being expressed in those species by furrows along arches $\mathbf{D L}$ and $\mathbf{V L}$; from Ceratocyrtis mashae Bjørklund, 1976 in the latter's cephalis being incorporated into the thoracic cavity and in the thorax of the latter tapering distally; from Gondwanaria reshetnjakae (Petrushevsakaya, 1967) and G. campanulaeformis (Campbell \& Clark, 1944) (= Sethoconus dogieli Petrushevskaya, 1967) primarily in the first one having no distinct collar stricture and in the second having an apically elongated cephalis with well-expressed arches ap (see Funakawa 2000).

Family Pterocorythidae Haeckel, 1881 emend. Riedel, 1967 emend. Moore, 1972

Genus Anthocyrtidium Haeckel, 1881

Type species. Anthocyrtis ophirensis Ehrenberg, 1873

\section{Anthocyrtidium sp.}

(Pl. 5, figs 1A-2B)

Material. Six specimens observed in DSDP Site 278 and ODP Sites 751 and 1138. 
Description. Two-segmented nassellarian with an apically elongated cephalis and a long, barrel-shaped to spindle-shaped thorax. As for the type species of the genus, the cephalis is separated in an elongated eucephalic lobe that extends far up on the apical horn, and two lateral lobes separated from the former by arches ap (Pl. 5, fig. $1 \mathrm{~A}-\mathrm{C})$ and situated at the base of the cephalis, below the eucephalic chamber. The cephalis bears a few randomly distributed small circular pores, mostly on the basal part of the cephalis. The apical horn is fairly long, blade-shaped with a thickened base (because of the eucephalic chamber extending over it). Spines LI and Lr seem particularly thick (see Pl. 5, fig. 1C). The collar is characterized by a change in contour but no clear stricture. The thorax is long, barrel-shaped to spindle-shaped. Its termination is a relatively wide hyaline, tapering peristome, not demarcated from the rest of the thorax by any change in contour or any thickening. Several small, triangular teeth extend from its base, at regular intervals. The pores on the lower part of the thorax are aligned longitudinally, small, circular and are rather widely spaced. These pore rows are separated by thin ridges (see Pl. 5, fig. 1A). Pores are arranged, transversally, in quincunx. On the upper part of the thorax, though, the pores are more irregularly spaced, with occasionally large areas of smooth, hyaline wall between them, and their longitudinal alignment is less regular. One specimen (P1. 5, fig. 2A-B) exhibits a thin line on the shell wall between the upper and the lower part of the thorax (as delimited by the different pore pattern). Although this might be purely taphonomical it could also be the mark of the fusion between a true thorax (which we referred to earlier as the 'upper thorax') and an abdomen (the 'lower thorax'). Other specimens (Pl. 5, fig. 1A-C), however, do not show such a line.

Dimensions. (of the two specimens illustrated) Total length: 168190; maximum width: 81-95; length of cephalis (including apical horn): 79-80.

Occurrence. A few specimens have been observed in the Eucyrtidium punctatum Zone (Middle Miocene) of Sites 278 and 751 and some others in the Amphymenium challengerae Zone (Late Miocene) of Site 1138.

Remarks. The cephalis of Anthocyrtidium sp. corresponds exactly to that described for the genus in Sanfilippo \& Riedel (1992). It is, in particular, almost identical to that of Anthocyrtidium stenum Sanfilippo \& Riedel, 1992, with the exception that the two lateral lobes are somewhat narrower in our specimens. Apart from this detail, they differ in $A$. sp. termination and in A. stenum abdomen. Anthocyrtidium adiaphorum Sanfilippo \& Riedel, 1992 differs also from $A$. sp. for the same two reasons.

Anthocyrtidium ehrenbergi (Stöhr, 1880), A. ophirensis (Ehrenberg, 1873), A. zanguebaricum (Ehrenberg, 1873), A. angulare Nigrini, 1971, A. euryclathrum Nigrini \& Caulet, 1988, A. jenghisi Streeter, 1988 and A. michelinae Caulet, 1979 all differ from our specimens in the shape of their thorax (generally campanulate) and their thorax porosity (mainly their higher pore density but also in the pore's shape and size). A. nosicaae Caulet, 1979 has a more elongated thorax, more similar to that of our specimens, but its pores are larger and compactly arranged. The same can be said for A. prolatum Nigrini \& Caulet, 1988 and A. pliocenica Seguenza, 1880 , which have a thorax outline roughly similar to that of $A$. sp. but differ in their porosity and, in the case of $A$. pliocenica, in having a second row of teeth above the basal opening. The shell outline is reminiscent of that of Lamprocyrtis junonis (Haeckel, 1887) $(=$ ? Lamprocyrtis hannai (Campbell \& Clark, 1944)) but they differ in their porosity and in the latter being separated into two segments by a clear lumbar stricture. Similarly, it differs from Pterocorys clausus (Popofsky, 1913) in the latter's lumbar structure, its row of terminal teeth and in the cephalic structure.
The patchy occurrence pattern observed for $A$. sp. is similar to the observed overall patchiness of Pterocorythidae occurrences in the Southern Ocean: it is probable that $A$. sp was not, in fact, a typically Antarctic species but rather a Subantarctic or even, perhaps, Subtropical species.

The two illustrated specimens are the only complete specimens observed to date, hence we have left this species in open nomenclature.

Family Plagiacanthidae Hertwig, 1879 emend. Petrushevskaya, 1971

Genus Enneaphormis Haeckel, 1881 emend. Petrushevskaya, 1971

Type species. Enneaphormis rotula Haeckel, 1881

Enneaphormis tippula $\mathrm{n}$. sp.

(Pl. 6, figs $1 \mathrm{~A}-4)$

Derivation of name. From the Latin tippula, water bug.

Diagnosis. Cephalic cap; three smooth spines joined by a smooth ring.

Material. Fourteen specimens in DSDP Site 278 and ODP Sites 689, 746, 748 and 751.

Holotype. Plate 6, figure 4A-B; sample 119-746A-5H-1, 53-55 cm (Late Miocene); ECO-070, circle 2.

Description. Three large, cylindrical spines arising from spines $\mathbf{D}, \mathbf{L I}$ and $\mathbf{L r}$ constitute the frame of that species' skeleton. Proximally, the cephalic wall diverges from these spines to form a network of anastomosed bars forming a hemispherical cap. Pores delimited by these bars are polygonal, irregular in size and shape and closely packed. Distally, arches diverge also from these spines to form a ring. This ring is usually circular but can, in some specimens, be somewhat hexagonal (as in the type species of the genus). The three spines continue after the ring. Under the cephalic cap, in addition to the well-developed spines $\mathbf{D}, \mathbf{L l}$ and $\mathbf{L r}$, spines $\mathbf{M B}$ and $\mathbf{A}$ are clearly distinguished. MB is relatively long - which explains why the three main spines do not join at the centre of the cephalic cap but that their junction is somewhat eccentric; see for example Plate 6, fig. 4A-B - and aligned with spine D. Spine A is short, directed vertically, joins the cephalic cap subapically and protrudes as a very short, needle-like horn.

Dimensions. Based on three specimens. Diameter of cephalic cap: 44-52 (47); diameter of arch ring: 74-88 (82).

Occurrence. Sporadic from the Cycladophora golli regipileus Zone to the Cycladophora spongothorax Zone (Early to Late Miocene).

Remarks. Its circular ring and the hemispherical latticed cephalic cap seem characteristic enough to unambiguously differentiate this form from related forms such as Enneaphormis rotula Haeckel, 1881, Sethophormis aurelia Haeckel, 1881 and Enneaphormis sp. Renaudie \& Lazarus, 2013a. In particular, Enneaphormis rotula has a cephalic velum (when present) that is attached to the ring rather than halfway between the centre and the ring, and usually possesses additional spines arising from the ring, between the three main ones.

Genus Euscenarium Haeckel, 1887 emend. Petrushevskaya, 1981

Type species. Euscenium tricolpium Haeckel, 1887

Euscenarium funakawai $\mathrm{n}$. sp.

(Pl. 6, figs 6A-7B, 10, 13) 

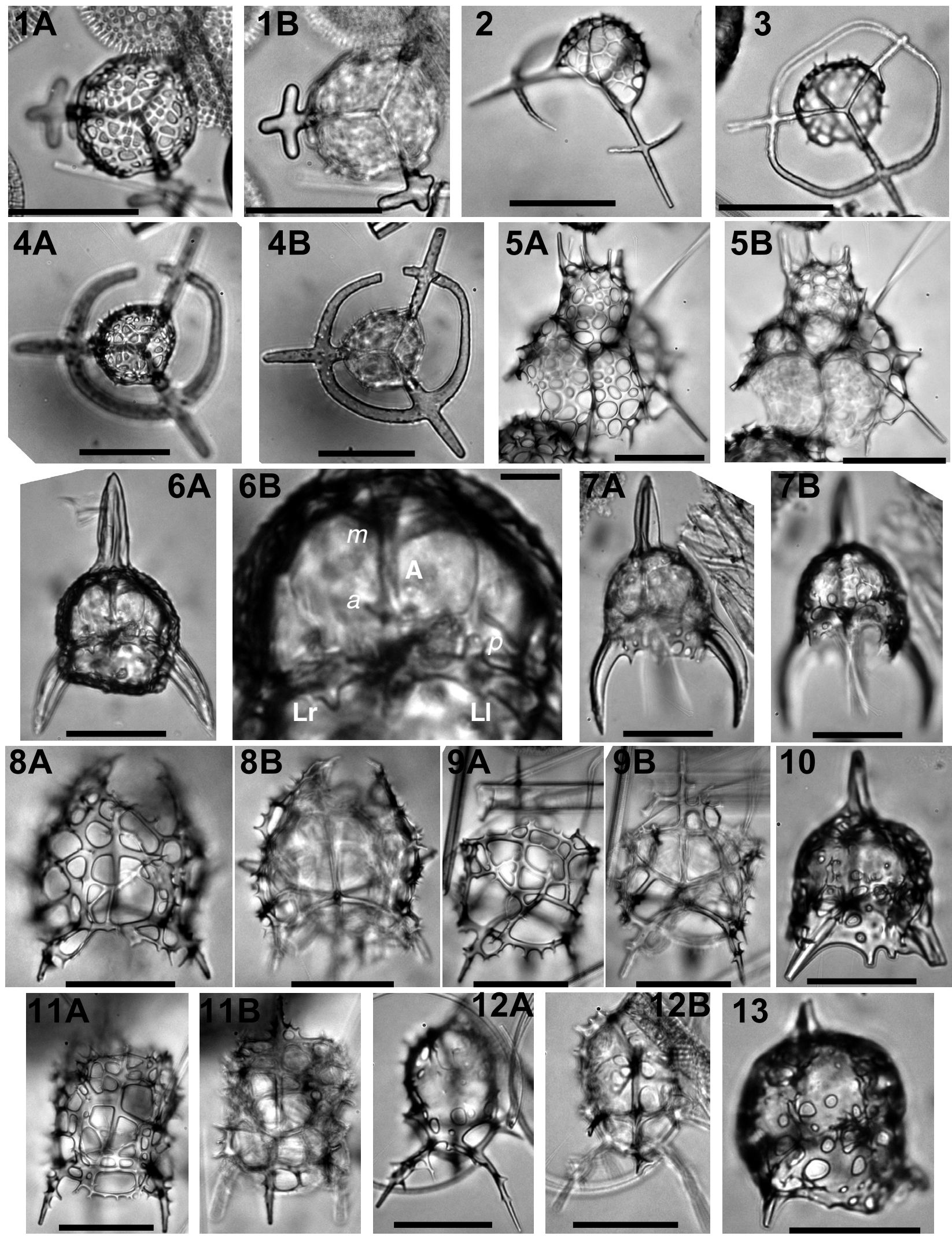

Explanation of Plate 6. figs 1-4. Enneaphormis tippula n. sp.: 1A, B, sample 113-689B-4H-2, 101-108 cm - (A) focus on cephalic cap wall, (B) focus on spines D, LI and $\mathbf{L r}$; 2, sample 120-748B-6H-2, 45-47 cm; 3, sample 120-751A-12H-6, 98-102 cm - basal view; 4A, B, sample 119-746A-5H-1, $53-55 \mathrm{~cm}-$ (A) focus on cephalic cap wall, (B) focus on ring. fig. 5A, B. Lophophaena kamikurii?, sample 120-751 A-4H-3, 98-102 cm - (A) focus on shell wall, (B) focus on internal structure. figs 6, 7, 10, 13. Euscenarium funakawai $\mathrm{n}$. sp.: 6A, B, sample 119-744A-8H-1, 60-62 cm, holotype - (A) full specimen in ventral view, (B) zoom on inner structure; 7A B, sample 120-747A-9H-2, 45-47 cm - (A) focus on spine A, (B) focus on shell wall; 10, sample 120-748B-6H-3, 45-47 cm; 13, sample 120-748B-6H-1, 45-47 cm. figs 8, 9, 11. Phormacantha garbela $\mathrm{n}$. sp.: 8A, B, sample 120-748B5H-4, 45-47 cm - (A) focus on shell wall, (B) focus on spine A; 9A, B, sample 120-748B-5H-7, 45-47 cm - (A) focus on shell well, (B) focus on spine A; 11 A, B, sample 120-748B-5H-7, 45-47 cm, holotype - (A) focus on shell well, (B) focus on spine A. fig. 12A, B. Phormacantha garbela?, sample 183-1138A-14R-2, 50-52 cm - (A) focus on shell well, (B) focus on spine A. All scale bars $50 \mu \mathrm{m}$ except 6B for which it is $10 \mu \mathrm{m}$. $a$, anterior apophyse; $m$, mitral apophyse; $p$, pectoral apophyse; $\mathbf{A}$, apical spine; $\mathbf{L r}$, right lateral spine; $\mathbf{L l}$, left lateral spine. 
1994 Euscenarium sp. aff. E. tricolpium (Haeckel); Funakawa: 477, pl. 15, fig. 1a-b.

Derivation of name. Named after Satoshi Funakawa who first illustrated this species.

Diagnosis. Small Clathromithrinae with thick, almost poreless wall, a lanceolate apical horn and three short, tribladed feet.

Holotype. Plate 6, figure 6A-B; sample 119-744A-8H-1, 60-62 cm (Early/Middle Miocene); ECO-092.

Material. Thirty-two specimens in DSDP Site 278 and ODP Sites 744, 747, 748 and 751.

Description. Dicyrtid with a hemispherical cephalis and a short thorax, separated externally from one another by barely distinguishable furrows along arches DL and VL. The cephalic wall is thick and in most specimens almost poreless. Pores, when present, are small, more or less circular and irregularly arranged. Some crests can also be seen on the wall. The thorax is often ragged but in some specimens is closed; it is usually less thick than the cephalic wall and bears more pores. Spine $\mathbf{A}$ is free in the middle of the cephalic cavity, joins the cephalic wall apically and protrudes as a thick, lanceolate, tribladed horn. Apophyses $m$ can clearly be seen (Pl. 6, fig. 6B) extending from spine A close to the junction with the cephalic wall and joining it at the lateral roots of the horn. Apophyses $a$ are distinct in some specimens (see Pl. 6, fig. 6B) as little triangular projections on spine $\mathbf{A}$ at mid-height of the cephalis. Spines $\mathbf{D}, \mathbf{L I}$ and $\mathbf{L r}$ all protrude as downward-directed, curved, tribladed feet, of approximately the same size as the apical horn. Apophyses $c$ (Pl. 6, fig. 7A) and $p$ (Pl. 6, fig. 6B) can be seen either as little projections (similar to $a$ ) or as thin rods connecting to the cephalic wall on, respectively, spines $\mathbf{D}$ and $\mathbf{L I} / \mathbf{L r}$. Spine $\mathbf{V}$ is thin, projects from $\mathbf{M B}$ at a rather wide angle with spine $\mathbf{A}$ and connects the cephalic wall. Some specimens (see Pl. 6, fig. 13) show a small ventral horn (including the specimen illustrated by Funakawa 1994). The axial projection (Ax) is hardly distinguishable but can be seen in some specimens (see the specimen illustrated by Funakawa 1994) as small lumps on MB. As Funakawa (1994) noted, furrows along $\mathbf{A L}$ and $\mathbf{A D}$ can be seen slightly constricting the cephalic wall longitudinally (see Pl. 6, figs 10 and 13).

Dimensions. Based on 4 specimens. Height of shell without horn and feet: 58-71 (69); width of shell at MB: 57-66 (62); height of apical horn: 35-51 (44); length of feet: 42-62 (52).

Occurrence. Rare from the Cycladophora golli regipileus Zone to the Cycladophora humerus Zone (Early to Middle Miocene). Funakawa (1994), however, observed this species in the Late Miocene of Japan.

Remarks. Euscenarium tricolpium (Haeckel, 1887) and E. joergenseni (Dumitrica, 1978), while sharing their general spicular structure as well as the presence of a poorly-developed thoracic wall (see Funakawa 1994), differ from E. funakawai n. sp. in the latter having a complete, thick, poreless cephalic wall and in its feet being short, angled and downward-directed instead of laterally-projected, long and serrated. This species differs from Clathrocanium coarctatum Ehrenberg, 1861 emend. Petrushevskaya, 1971 and C. sphaerocephalum Haeckel, 1887 primarily in these two species having large well-developed arches connecting feet $\mathbf{D}, \mathbf{L l}$ and $\mathbf{L r}$ terminally, but also in them lacking a thoracic wall.

Genus Lophophaena Ehrenberg, 1847 sensu Petrushevskaya, 1971

Type species. Lophophaena galeaorci Ehrenberg, 1854

Lophophaena rhopalica $\mathrm{n}$. sp. (Pl. 7, figs 2, 5-6; ?Pl. 7, figs 8-9)
Derivation of name. From the Greek-derived Latin adjective rhopalicus meaning 'shaped like a club, a bludgeon'.

Diagnosis. Characteristic large ball-shaped cephalis wider than the thorax; collar structure characterized by a series of large pores with a ventral-to-dorsal size gradient.

Holotype. Plate 7, figure 2; sample 120-748B-6H-6, 45-47 cm (Early Miocene); ECO-093

Material. Twenty-five specimens from DSDP Site 278 and ODP Sites 748 and 1138 .

Description. Two-segmented forms with a large and thick cephalis representing at least half of the height of the shell and a narrower, cylindrical thorax. The cephalic wall is thick and crested, sometimes elongated longitudinally, and bears circular pores whose size decreases toward the apex of the shell. They are regularly arranged in an hexagonal pattern. They often have raised frames (Pl. 7, figs 2 and 5). There is a clear constriction at the collar. The collar itself is constituted by what seems to be a ring linking $\mathbf{A}$ and $\mathbf{V}$ at the base of the cephalic chamber. A few, thicker, downward-directed bars arise from this ring, thus delimiting large pores. The thoracic wall seems to be connected to these bars (see Pl. 7, figs 2, 5-6), though it often continues above them (see Pl. 7, figs 2 and 5). The pores delimited by the bars are uneven in size as there is a size gradient from smaller pores on the ventral side to larger ones on the dorsal side. Spine A can be seen on some specimens (see specimen in dorsal view, Pl. 7, fig. 5): it is fused to the cephalic wall and does not protrude as a horn. There seem to be a series of pore pairs at the junction of spine $\mathbf{A}$ and the cephalic wall.

Dimensions. Based on three specimens. Width of cephalis: 57-65 (62); width of thorax: 45-64 (54); width at collar stricture: 30-35 (33); length of cephalis: 56-84 (68).

Occurrence. Rare in the Cycladophora golli regipileus Zone (Early Miocene). One specimen, possibly reworked, was observed in the Cycladophora spongothorax Zone (Middle Miocene) of site 1138 .

Remarks. The collar structure seems somewhat similar to what we observed in the Antarctic specimens of Lophophaena macrencephala Clark \& Campbell, 1945 and the specimens illustrated as $L$. macrencephala group in Dzinoridze et al. 1978 but differs from these forms in its thick, thornless cephalis and its short, thin, veillike thorax. The junction between the cephalis and the thorax of $L$. rhopalica $\mathrm{n}$. sp. evokes somewhat that seen in most complete specimens of Arachnocorallium calvata (Haeckel, 1887) or A. stilla Renaudie \& Lazarus, 2015 (see discussion in Remarks for that species). However, none of the long basal spines seen in the species of Arachnocorallium can be seen here.

Lophophaena kamikurii n. sp.

(P1. 7, figs 10A-12; ?Pl. 6, fig. 5A-B)

Derivation of name. Named after Shin-Ichi Kamikuri for his contribution to the Neogene radiolarian taxonomy.

Diagnosis. Large irregular, thorn-bearing cephalis; thin-walled shell with numerous pores.

Holotype. Plate 7, figure 10A-B; sample 120-751A-1H-1, 98-102 cm (Pleistocene); ECO-094.

Material. 149 specimens from ODP Sites 689, 748, 751 and 1138.

Description. Dicyrtid nassellarian with a large irregular hemispherical cephalis bearing thorns and a wider, larger subcylindrical thorax. The cephalis bears numerous triangular thorns, mostly toward the apex. It is perforated by numerous, randomly distributed, elliptical 

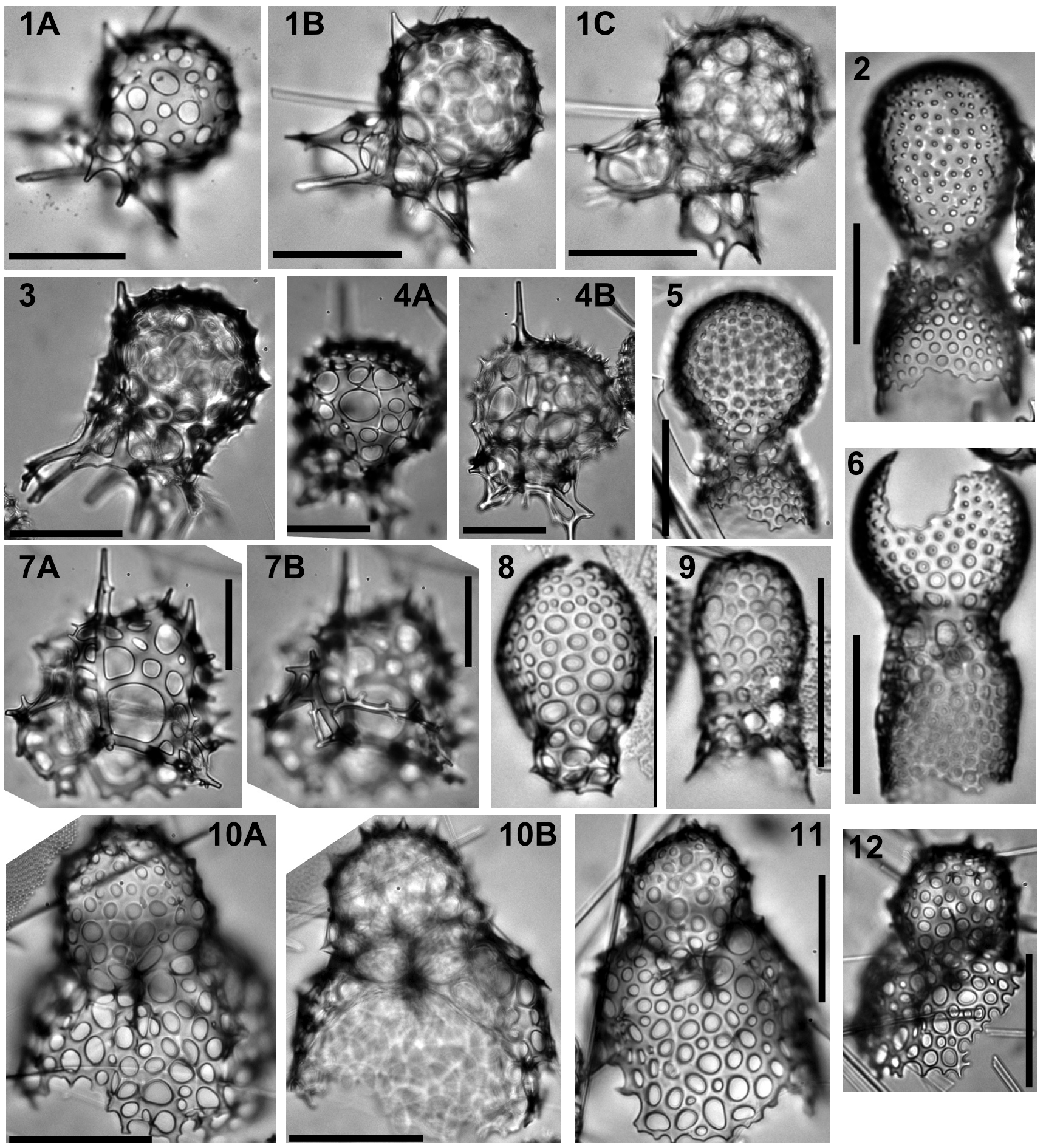

Explanation of Plate 7. figs 1, 3, 4. Peridium tortonianicum n. sp.: 1A-C, sample 183-1138A-17R-3W, 50-52 cm - (A) focus on cephalic wall, (B) focus on arch $\mathbf{A L},(\mathrm{C})$ focus on arch AD; 3, sample 119-744A-5H-1, 53-55 cm, holotype; $\mathbf{4 A}, \mathbf{B}$, sample 119-744A-5H-1, 53-55 cm - (A) focus on cephalic wall, (B) focus on spine A. fig. 7A, B. Peridium tortonianicum?, sample 119-746A-7H-6, 53-55 cm - (A) focus on spine A, (B) focus on arch AD. figs 2, 5, 6. Lophophaena rhopalica $\mathrm{n}$. sp.: 2, sample 120-748B-6H-6, 45-47 cm, holotype; 5, sample 120-748B-6H-CC; 6, sample 120-748B-7H2, 45-47 cm. figs 8, 9. Lophophaena rhopalica?: 8, sample 120-748B-7H-2, 45-47 cm; 9, sample 120-748B-7H-2, $45-47 \mathrm{~cm}$. figs 10-12. Lophophaena kamikurii n. sp.: 10A, B, sample 120-751A-1H-1, 98-102 cm, holotype - (A) focus on shell wall, (B) focus on spines LI and Lr; 11, sample 120-751A$1 \mathrm{H}-1,98-102 \mathrm{~cm} ; 12$, sample $120-751 \mathrm{~A}-1 \mathrm{H}-1,98-102 \mathrm{~cm}$. Scale bars represent $50 \mu \mathrm{m}$.

pores of various sizes. Pores on the thoracic wall are similar but more closely packed. The thoracic wall also bears some smaller thorns, now and then, arising from bar nodes. Specimens (see Pl. 7, figs $10 \mathrm{~A}$ and 11) often bear larger pores at the collar. The collar is expressed as a stricture, with furrows along AL and VL (see Pl. 7, fig. 11). MB is situated slightly lower than the external collar stricture. Spine $\mathbf{A}$ joins the wall at the collar and spine $\mathbf{V}$ somewhat higher; they do not seem to protrude as horns. Spines $\mathbf{L I}$ and $\mathbf{L r}$ are spread widely and join the wall relatively high on the thoracic wall. Spine D was not observed.

Dimensions. Based on six specimens. Length of cephalis: $60-70$ (64); width of cephalis: 54-71 (62); width of thorax: 86-116 (101).

Occurrence. Sporadic from the lower Upsilon Zone (Late Pliocene), rare to common from the upper Chi to the Omega Zone (Pleistocene). 
Remarks. The shell evokes at first glance that of contemporaneous species, such as Antarctissa strelkovi Petrushevskaya, 1967, A. fragea Renaudie \& Lazarus, 2015 and Helotholus praevema Weaver, 1983; however, they differ in that our new species lacks a strong downward-directed spine $\mathbf{D}$, has an irregular, large, hemispherical cephalis shape and numerous thorns. Conversely, its cephalis evokes that of the also contemporaneous Lophophaena nadezdae Petrushevskaya, 1971 but its wide thorax, thinner shell and larger pores make a clear distinction between these two species. Additionally it differs from Amphiplecta tripleura Funakawa, $1995 a$ in lacking the external arch AD and the large pores surrounding it; and from Lithomelissa setosa Jørgensen, 1900 in the latter having an elongated cephalis and being considerably smaller.

Genus Peridium Haeckel, 1887

Type species. Peridium lasanum Haeckel, 1887

Peridium tortonianicum $\mathrm{n}$. sp. (Pl. 7, figs 1A-C, 3-4B; ?Pl. 7, fig. 7A-B)

Derivation of name. Named after the ICS stage Tortonian, during which this species seem to have lived, with the adjective termination-icus.

Holotype. Plate 7, figure 3; sample 119-744A-5H-1, 53-55 cm (Late Miocene); ECO-095.

Material. 96 specimens in ODP Sites 744, 747, 751 and 1138.

Description. The shell consists of a large subspherical to globular eucephalic chamber and a large, thick initial spicule. Some specimens show some additional bars that seem to form a somewhat loose thorax (see Pl. 7, fig. 1A-C, for instance). The initial spicule consists of spines $\mathbf{A}, \mathbf{V}, \mathbf{D}, \mathbf{M B}, \mathbf{L l}$ and $\mathbf{L r}$, with, in addition to that, an axobate sometimes visible as a small protuberance on MB. An arch AD is clearly visible on most specimens (Pl. 7, figs 3A and 7B; ?P1. 7, fig. 1B). The cephalic chamber is connected to spine $\mathbf{A}$ once subapically but also in two or three lower points (see Pl. 7, figs $4 \mathrm{~B}$ and 7A). It lies on clearly expressed arches $a p$ (i.e. AL) and on spine $\mathbf{V}$. Whereas spine $\mathbf{A}$ continues as an apical horn with a broad base, spine $\mathbf{V}$ does not. Spines $\mathbf{L I}$ and $\mathbf{L r}$ are rather short, but spine $\mathbf{D}$ can be longer (see Pl. 7, fig. 1A-C, for instance). Pores on the cephalic wall are irregular in size, with very large pores interspaced with very small pores as in Plate 7, figures $1 \mathrm{~A}$ and $4 \mathrm{~A}$, but are generally all elliptical. The bars between the pores are thick and crested, and can sometimes also bears thorns (see Pl. 7, figs 4B and 7A). When some thoracic bars are present, the two external segments are separated at the level of arches ap (P1. 7, fig. 1A-B).

Dimensions. Based on four specimens. Maximum width of cephalis: 71-99 (72); height from MB to apex: 84-100 (88); length of spine A from MB to tip of apical horn: 80-138 (84).

Occurrence. Rare in the Cycladophora spongothorax Zone (Late Miocene), sporadic until the Siphonosphaera vesuvius Zone (Late Miocene).

Remarks. This species differs from Arachnocorallium cerebellum Renaudie \& Lazarus. 2015 and from Peridium sphaerum Funakawa, $1995 b$ in these two species having a cephalis separated into upper globular and lower 'funnel-shaped' halves. They also both lack clearly expressed arches AL and AD. Peridium longispinum Jørgensen, 1900 is very similar to this new species, hence the generic assignment, but differs in its smaller size, thinner shell and spicule, the absence of a clearly expressed arch AD, and in having numerous thin by-spines. They share, however, the presence of arches AL and the shape of their spine A, more specifically the way the cephalic chamber is linked to it (see, for instance, Dolven et al. 2014, pl. 6, fig. 18). This character seems to be shared also by Phormacantha hystrix (Jørgensen, 1900), but this species differs from the latter two in lacking a proper latticed cephalic wall. It does possess, however, an external arch AD, as in our new species. Peridium minutum Cleve, 1899 (as illustrated in Bjørklund et al. 2014) differs from both $P$. longispinum and $P$. tortonianicum in its cephalic wall consisting of thin bars delimiting small, polygonal pores and in its large pair of pores at the junction between spine $\mathbf{A}$ and the cephalic wall, above the connection with arch AL.

Finally Peridium tortonianicum n. sp. differs from Lophophaena sp. D Petrushevskaya, 1971 (pl. 56, figs 3-4) in the latter possessing a proper thoracic wall and two additional subapical small spines similar to the apical horn. Spines $\mathbf{L}, \mathbf{L r}$ and $\mathbf{D}$ in the latter species are directed downwardly instead of more laterally in P. tortonianicum.

\section{Genus Phormacantha Jørgensen, 1905}

Type species. Peridium hystrix Jørgensen, 1900

Phormacantha garbela $\mathrm{n} . \mathrm{sp}$.

(Pl. 6, figs 8A-9B, 11A-B; ?Pl. 6, fig. 12A-B)

Derivation of name. From the Occitan garbèla which is a kind of wicker fishtrap, after the loose meshwork that forms this species' wall and the apical opening.

Diagnosis. Loose, apically elongated skeleton; spines $\mathbf{A}$ and $\mathbf{V}$ part of the cephalic wall; short, downward-directed feet $\mathbf{D}, \mathbf{L I}$ and Lr.

Holotype. Plate 6, figure 11A-B; sample 120-748B-5H-7, 45$47 \mathrm{~cm}$ (Early/Middle Miocene); ECO-096.

Material. Nine specimens from DSDP Site 278 and ODP Sites 689, 748 and 1138.

Description. Apically elongated, almost cylindrical, cephalic wall consisting of a random meshwork of bars of various thicknesses. The bar nodes often bear tiny thorns from which new, thinner, bars extend. The shell wall does not seem to be properly closed apically.

Spine $\mathbf{A}$ and spine $\mathbf{V}$ both join the cephalic wall and continue as upward-directed ribs (and eventually as conical horns). Spine A connects directly to the wall, while spine $\mathbf{V}$ connects at mid-height of the wall (see Pl. 6, fig. 11A). No specimen was seen in sagittal view so it is difficult to estimate the size of MB but all spines seem to converge to one point hinting that $\mathbf{M B}$ is probably very short. No Ax was observed. Spines $\mathbf{D}, \mathbf{L} \mathbf{l}$ and $\mathbf{L r}$ (each separated by an equal angle) extend to the bottom of the cephalic wall where they then continue downwards (in a direction almost parallel to that of the cephalic wall) as conical, thorny feet. The cephalic wall bars randomly connect to these feet in several places.

Dimensions. Based on four specimens. Height (from MB to tip of A): 73-95 (84); maximum width: 48-72 (69).

Occurrence. Found sporadically from the Cycladophora spongothorax to the Siphonosphaera vesuvius Zone (Middle to Late Miocene).

Remarks. This species differs from Plectacantha cresmatoplegma Nigrini, 1968 in lacking strong arches near MB between spines LI and $\mathbf{L r}$ and in lacking secondary spines. The last point is also what distinguishes this new species from Plagiacantha panarium Dumitrica, 1973. It differs from Plectacantha oikiskos Jørgensen, 1905 and $P$. trichoides Jørgensen, 1905 in its long spine $\mathbf{V}$, in its apically elongated cephalic wall and in spines $\mathbf{D}, \mathbf{L} \mathbf{l}$ and $\mathbf{L r}$ being expressed externaly as short, downward-directed feet. The last two characters are also what separate this species from Phormacantha hystrix, the type species of the genus. 

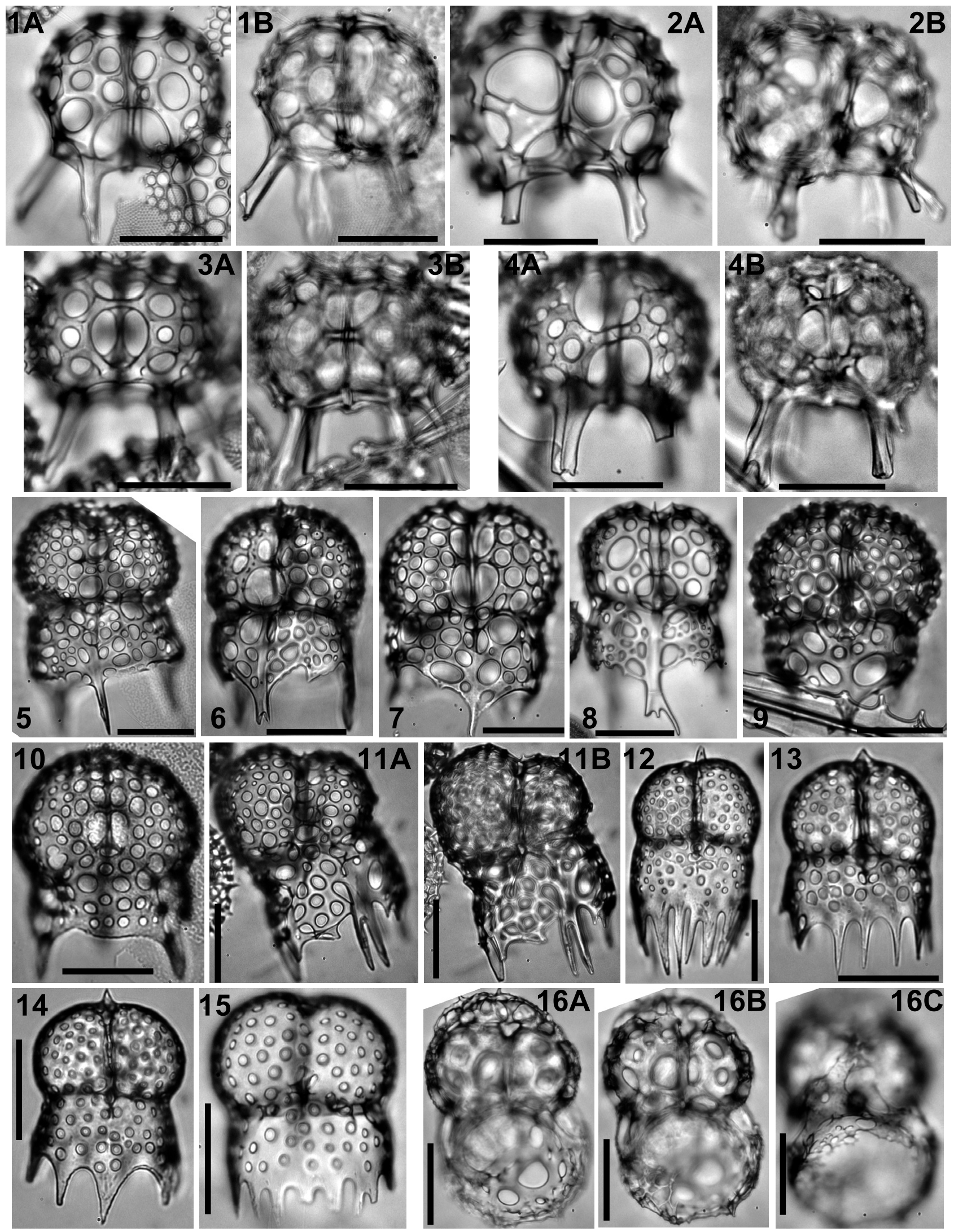

Explanation of Plate 8. figs 1-4. Dendrospyris quadripes n. sp.: 1A, B, sample 120-748B-8H-6, 45-47 cm, holotype - (A) ventral side, (B) dorsal side; 2A, B, sample 120-748B-8H-6, 45-47 cm - (A) ventral side, (B) dorsal side; 3A, B, sample 120-748B-8H-6, 45-47 cm - (A) dorsal side, (B) ventral side; 4A, B, sample 120-748B-8H-6, 45-47 cm - (A) ventral side, (B) dorsal side. figs 5-9. Phormospyris punnulis n. sp.: 5, sample 119-744A-10H-2, 60-62 cm - dorsal view; 6, sample 119-744A-10H-2, 60-62 cm, holotype - dorsal view; 7, sample 119-744A-10H-2, 60-62 cm - dorsal view; 8, sample 120-747A-1H-5, 45-47 cm - dorsal view; 9, sample 120-748B-6H-5, 45-47 cm - dorsal view. figs 10-11. Phormospyris punnulis?: 10, sample 119-744A-10H-2, 60-62 cm - ventral view?; 11A, B, sample 120-748B-6H-5, 45-47 cm - (A) dorsal side, (B) ventral side. figs 12-15. Rhodospyris pulchra $\mathrm{n}$. sp.: 12, sample 119-744A-10H-2, 60-62 cm; 13, sample 119-744A-10H-2, 60-62 cm, holotype; 14, sample 119-744A-10H-2, 60-62 cm; 15, sample 120-748B-7H-2, 45-47 cm. fig. 16A-C. Tholospyris tautessares $\mathrm{n}$. sp., sample 120-748B-6H-1, 45-47cm - (A) focus on apex, (B) focus on cephalic wall, (C) focus on thoracic wall. Scale bars represent $50 \mu \mathrm{m}$. 
The specimen illustrated in Plate 6, figure 12A-B has a proper, smooth cephalic wall and thus differs from the holotype. However, the arrangement of its spines and its feet make us believe it belongs to this new species. It might simply represent either a more advanced stage of cephalic wall building or a particularly heavily silicified specimen.

Family Trissocyclidae Haeckel, 1881 emend. Goll, 1968

Genus Ceratospyris Ehrenberg, 1847

Type species. Haliomma radicatum Ehrenberg, 1844

Ceratospyris clarki $\mathrm{n}$. sp.

(P1. 9, figs 3, 9A-11B, 13A-14B; ?P1. 9, fig. 12A-B)

?1978 Ceratospyris cf. radicata Ehrenberg; Dumitrica: pl. 7, fig. 26.

Derivation of name. Named after Bruce L. Clark, for his contribution to Cenozoic radiolarian taxonomy.

Diagnosis. No sagittal constriction; large pairs of sagittal-lattice pore on the dorsal side; shell wall extends shortly below the basal ring.

Holotype. Plate 9, figure 14A-B; sample 119-744A-9H-1, 60$62 \mathrm{~cm}$ (Early Miocene); ECO-097.

Material. 278 from DSDP Site 278 and ODP Sites 690, 693, 744, 747, 748, 751 and 1138 .

Description. Shell divided in two lobes by a relatively wide sagittal ring which is not marked by any external constriction. The apex of the shell is the apex of the sagittal ring, where spine $\mathbf{A}$ sometimes forms a small apical horn. On the dorsal side, two pairs of sagittallattice pores can be seen, the lowermost being the larger, and being elliptical, elongated in the direction of the sagittal ring. On the ventral side, three large pairs of sagittal-lattice pores are present. Other pores present on the cephalic wall are smaller, quite numerous, more or less circular and irregularly distributed. The shell wall continues below the basal ring to form a very short thorax. The basal constriction is marked only by a slight change in contour.

Dimensions. Based on nine specimens. Total height: 72-91 (78); maximum width: 74-102 (85); long axis of lowermost sagittallattice pore pair: 18-32 (26); long axis of upper sagittal-lattice pore pair: 6-24 (14).

Occurrence. Rare from the Clinorhabdus longithorax Zone to the Eucyrtidium punctatum Zone (Early to Middle Miocene), except in the transition between the Cycladophora golli regipileus Zone and the E. punctatum Zone (Early Miocene) where it is more common. Sporadic until the Upsilon Zone (Early Pliocene).

Remarks. The species described herein appears to differ also from Tristylospyris lunadae Campbell \& Clark, 1944. This is based primarily on the description given by these authors, as their image of this species is very poor, and attempts by the junior author to find this species in the type series material deposited at the Natural History Museum in Berkeley found only one ambiguous specimen. In comparison to T. lunadae, our species differs in lacking the three distinct feet, and in possessing large pairs of sagittal-lattice pores.

Genus Dendrospyris Haeckel, 1881 emend. Goll, 1968

Type species. Ceratospyris stylophora Ehrenberg, 1874

Dendrospyris quadripes $\mathrm{n}$. $\mathrm{sp}$.

(Pl. 8, figs 1A-4B)

?1944 Tristylospyris pacifica Campbell \& Clark: 33, pl. 5, fig. 9.

?1944 Tristylospyris herdisae Campbell \& Clark: 34, pl. 5, fig. 12.
Derivation of name. Named after its four basal feet.

Diagnosis. Triospyrid with four feet and large pairs of sagittallattice pores.

Holotype. Plate 8, figure 1A-B; sample 120-748B-8H-6, 45$47 \mathrm{~cm}$ (Late Oligocene); ECO-098.

Material. Six specimens were observed from ODP Site 748.

Description. Bilobed cephalis with a weak sagittal constriction and a flattened apex. Pores on the shell are large and elliptical. They are regularly arranged and separated by thick, crested bars with raised apices. On the ventral side, two pairs of large pores join the shell wall and the sagittal ring: the bars between the two pairs join the ring at mid-height (see Pl. 8, fig. 4A for instance). On the dorsal side also, one pair (the upper one) is smaller than the other (see Pl. 8, fig. 3A). Some specimens have extra bars splitting one of these pairs of sagittal-lattice pores in two (see Pl. 8, fig. 1). Spine $\mathbf{D}$ was not seen. Spine $\mathbf{V}$ can be seen in some specimens (see Pl. 8, figs $1 \mathrm{~A}$ and $4 \mathrm{~A}$ ) as a small protuberance at the junction of the sagittal ring with spines $\mathbf{L} \mathbf{l}$ and $\mathbf{L r}$. Spines $\mathbf{L} \mathbf{l}$ and $\mathbf{L r}$ terminate as robust, tribladed, downward-directed feet. Similarly, both spines l' continue as robust (though seemingly less robust than the previous two; see P1. 8, fig. 3B), tribladed, downward-directed (almost sideways in some specimens) feet. Both pairs of feet often bifurcate distally at their end (see Pl. 8, figs 2B and 4B). One particular feature of this species' basal ring is that it lacks an arch $\mathbf{L} \mathbf{L}$ or $\mathbf{V L}$ (see Pl. 8, figs 1A, 2A and 4A).

Dimensions. Based on 5 specimens. Height of the sagittal ring: 62-79 (72); maximum width: 87-107 (96).

Occurrence. All specimens were observed in two samples of the Stylosphaera radiosa Zone (latest Oligocene/Earliest Miocene) of ODP Site 748.

Remarks. It differs from Dendrospyris pododendros (Carnevale, 1908 ) in the latter having three basal spines and a frontal pore. It also differs from $D$. stylophora and from Triospyrium scopae Kozlova, 1999 in lacking an apical spine and in the latticed shell being connected to the sagittal ring by large pairs of pores. While Tristylospyris pacifica and T. herdisae, both described by Campbell \& Clark (1944), seem rather similar, the descriptions for these species clearly state that they possess a well-developed sagittal stricture, which is lacking in D. quadripes. The published images for these species are too poor to use for species distinctions, and examination of Clark \& Campbell's type series material by the junior author could find no specimens that fully matched the descriptions given by these authors. Specimens similar to our new species were seen in the Campbell and Clark material but, as they are not individually marked or clearly taxonomically labelled, it is not clear if they correspond to the two species described by them. D. quadripes finally differs from Ceratospyris laventaensis Campbell \& Clark, 1944, Phormospyris loliguncula Renaudie \& Lazarus, 2013a, Phormospyris coronata (Weaver, 1976) and P. punnulis $\mathrm{n}$. $\mathrm{sp}$. in that the latter species have a deeply constricted sagittal ring and numerous smaller pores on the two cephalic lobes.

Genus Phormospyris Haeckel, 1881 emend. Goll, 1976

Type species. Phormospyris tricostata Haeckel, 1887

Phormospyris punnulis $\mathrm{n}$. sp.

(Pl. 8, figs 5-9; ?Pl. 8, figs 10-11A-B)

?1976 Phormospyris stabilis antarctica (Haecker, 1907); Goll: pl. 4, figs 4-6 non 1-3, 7-9.

Derivation of name. From the Latin punnulis for 'skirt', after this species' thoracic wall. 
Diagnosis. Large sagittal-lattice pores on dorsal side; three robust feet emerging from a latticed thoracic wall.

Holotype. Plate 8, figure 6; sample 119-744A-10H-2, 60-62 cm (Early Miocene); ECO-091.

Material. 1244 specimens from DSDP Site 278 and ODP Sites $689,690,693,744,745,747,748,751$ and 1138 .

Description. Dicyrtid whose cephalis is separated into two lobes by a sagittal ring. The sagittal ring is usually shorter than the cephalis height, hence the sagittal constriction being deeply expressed. Pores on the two cephalic lobes are circular to elliptical, most of them rather large. The bars between the pores are thick and crested, usually with raised apices. The thorax and the cephalis are separated by a clearly expressed basal constriction as well. The thorax consists of three feet, often thick but rarely bladed, and a proper thoracic wall. Pores on the thoracic wall are relatively similar in size and shape to the ones on the cephalis, although some of them tend to be bigger (see, e.g. Pl. 8, fig. 9 or fig. 7). On the dorsal side, one large frontal pore can be seen. The bars surrounding it are connected on the upper side to the sagittal ring and on the lower side to the basal ring. In some specimens (Pl. 8, figs 6 and 9), a thin secondary feltwork is stretched over this pore. Above it, two pairs of sagittal-lattice pores, smaller than the frontal pore, can be seen. They are usually deeply set.

Dimensions. Based on seven specimens. Total height (including feet): 130-158 (144); height of sagittal ring: 59-74 (67); maximum width of cephalis: 102-117 (110); maximum width of thorax: 88-104 (96); diameter of sternal pore: 26-33 (29).

Occurrence. Common to rare from the Clinorhabdus longithorax Zone (Early Miocene) to the Amphymenium challengerae Zone (Late Miocene/Early Pliocene), then sporadic until the Upsilon Zone (Late Pliocene).

Remarks. This new species is clearly related to Phormospyris coronata (Weaver, 1976) but differs in P. punnulis having a welldeveloped thoracic wall when $P$. coronata has, at most, a thin feltwork developing between the basal spines (see, for instance, the specimen illustrated in Weaver 1983, pl. 2, fig. 2). Additionally, the sagittal-lattice pores of $P$. punnulis are larger and usually very deeply set. Similarly, $P$. punnulis differs from Phormospyris antarctica Haecker, 1907 and Phormospyris pacifica (Campbell \& Clark, 1944) in lacking apical thorns, in its more robust cephalic wall and, of course, in its thoracic wall. It also differs from Phormospyris loliguncula Renaudie \& Lazarus, 2013a in the latter having more than three feet; it, however, shares with that species their similar sagittal-lattice pores. The specimen illustrated in Goll (1976, pl. 4, figs 4-6 non 1-3, 7-9) as Phormospyris stabilis antarctica (Haecker) may be conspecific with $P$. punnulis, as it possesses a proper thoracic wall (as a difference to usual specimens of $P$. antarctica) but because the dorsal side of this specimen is not shown, the characteristic deeply-set sagittal-lattice pores were not observed. It finally differs from what Goll (1976) designates as Phormospyris stabilis stabilis (Goll, 1968) in possessing three robust feet and in its large pores, with thicker bars.

Genus Rhodospyris Haeckel, 1881

Type species. Rhodospyris tricornis Haeckel, 1887

Rhodospyris pulchra $\mathrm{n}$. sp. (Pl. 8, figs 12-15)

Derivation of name. From the Latin pulchrus meaning beautiful.

Diagnosis. Spyrid with no sagittal-lattice pores; thorax terminated in several long teeth.
Holotype. Plate 8, figure 13; sample 119-744A-10H-2, 60-62 cm (Early Miocene); ECO-060, circle 2.

Material. Seventeen specimens from DSDP Site 278 and ODP Sites 744 and 748 .

Description. Dicyrtid with a bilobed cephalis and a latticed thorax, both of approximately similar width. The cephalis is separated into two lobes by a sagittal ring. The sagittal constriction is weak, or not expressed at all. The basal constriction separating the two segments is, by contrast, deeper. Pores on the cephalis and on the thorax are randomly arranged, circular and small. They are all more or less of equivalent size. The shell wall is smooth. No sagittal-lattice pores are present. A relatively small sternal(?) pore can, however, be seen (see Pl. 8, fig. 13). Spine A is most often expressed externally as a small triangular horn at the summit of the sagittal ring. Spines $\mathbf{V}, \mathbf{D}, \mathbf{L} \mathbf{l}$ and $\mathbf{L r}$ were not observed. The thorax is terminated by a ring of numerous, long, triangular teeth. The thoracic wall on those teeth and a few $\mu \mathrm{m}$ above is smooth and devoid of pores. In some specimens (see Pl. 8, fig. 12), these teeth are directed inwards. The thoracic wall is relatively long even without the teeth. The teeth do not seem to be connected to any internal spines.

Dimensions. Based on four specimens. Total height: 104-141 (119); height of sagittal ring: 48-50 (49); height of thorax from basal ring to the root of the teeth: 33-44 (39); maximum width of the cephalis: 77-86 (82); maximum width of the thorax: 78-81 (78).

Occurrence. Rare from the Cycladophora antiqua to the Cycladophora golli regipileus Zones (Early Miocene).

Remarks. This species is very similar to two species described and illustrated by Haeckel (1887): Rhodospyris tricornis and Patagospyris anthocyrtis. However, it is distinguished from the first one in possessing only one apical horn and in its considerably shorter thorax (excluding teeth length), from the second primarily in its cephalis and apical horn shapes and sizes, and from both in its weak sagittal constriction. It differs also from Rhodospyris sp. aff. $R$. anthocyrtis Haeckel in Petrushevskaya \& Kozlova (1972) and in Ling (1975) in these forms lacking teeth and having a thorax flaring distally and large thoracic pores; from Rhodospyris sp. aff. R. tricornis Haeckel in Petrushevskaya \& Kozlova (1972) and Rhodospyris sp. De 1 (Goll) group in Nigrini \& Lombari (1984) in these forms having longitudinal rows of pores on their thorax and lacking the teeth ring. It finally differs from Dorcadospyris confluens (Ehrenberg, 1873) primarily in this species lacking a proper thorax and from Phormospyris stabilis (Goll, 1968) in its smooth shell, its apical horn and its terminal teeth.

\section{Rhodospyris? morleyi $\mathrm{n} . \mathrm{sp}$.}

(Pl. 9, figs 4-8)

Derivation of name. Named after Joseph J. Morley, early student of polar radiolarians.

Diagnosis. Spyrid with thorax slightly larger and wider than cephalis, and a basal constriction more marked than the sagittal constriction.

Holotype. Plate 9, figure 5; sample $120-748 \mathrm{~B}-8 \mathrm{H}-2,45-47 \mathrm{~cm}$ (Early Miocene); ECO-080, circle 3.

Material. Fifty-four specimens from DSDP Sites 278 and ODP Sites 748 and 751.

Description. Small dicyrtid nassellarian with a cephalis separated into two lobes by a relatively wide sagittal ring. The sagittal constriction is weak, but the basal constriction separating the cephalis from the thorax is stronger. The thorax is somewhat 


\section{Relative abundance (in \%)}

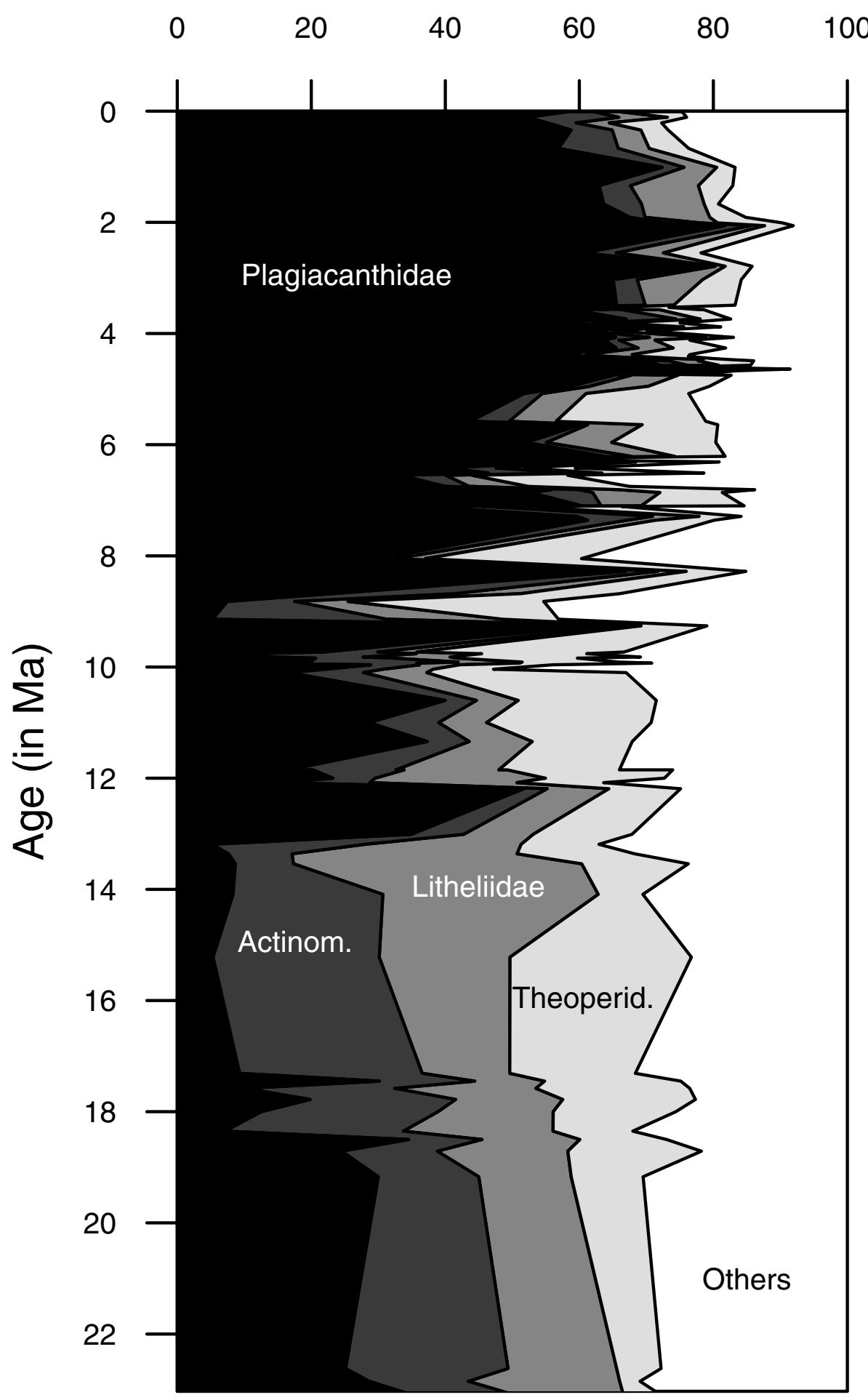

Fig. 4. Relative abundance of specimens from families Plagiacanthidae, Litheliidae, Theoperidae and Actinommidae in the Antarctic Neogene based on counts on 98 samples (see Renaudie \& Lazarus 2013b).

wider and longer than the cephalis. Thorax termination is ragged. The cephalic wall is somewhat thicker than the thoracic wall; both bear circular to slightly elliptical pores, regularly arranged. The thoracic pores are larger and more compactly arranged than the cephalic pores. Sagittal-lattice pores are similar to the wall lattice pores in shape and size. One side (ventral?) bears up to three pairs of such pores (see Pl. 9, fig. 7) while the other side (dorsal?) does not seem to bear any (see P1. 9, fig. 4). Apart from spine A that protrudes in some specimens as a short triangular horn (see Pl. 9, figs 4 and 7), the other internal spines are not clearly distinguishable.
Dimensions. Based on five specimens. Total height: 77-95 (82); height of sagittal ring: 38-46 (43); maximum width of the cephalis: 62-71 (68); maximum width of the thorax: 72-76 (73).

Occurrence. Rare to sporadic from the Stylosphaera radiosa Zone (latest Oligocene) to the Cycladophora humerus Zone (Middle Miocene).

Remarks. Phormospyris stabilis (Goll, 1968), Dendrospyris haysi Chen, 1975 and Dendrospyris rhodospyroides (Petrushevskaya, 1975) differ from this species in having a wider cephalis provided with more numerous pores. Dendrospyris pannosa Goll, 1968 

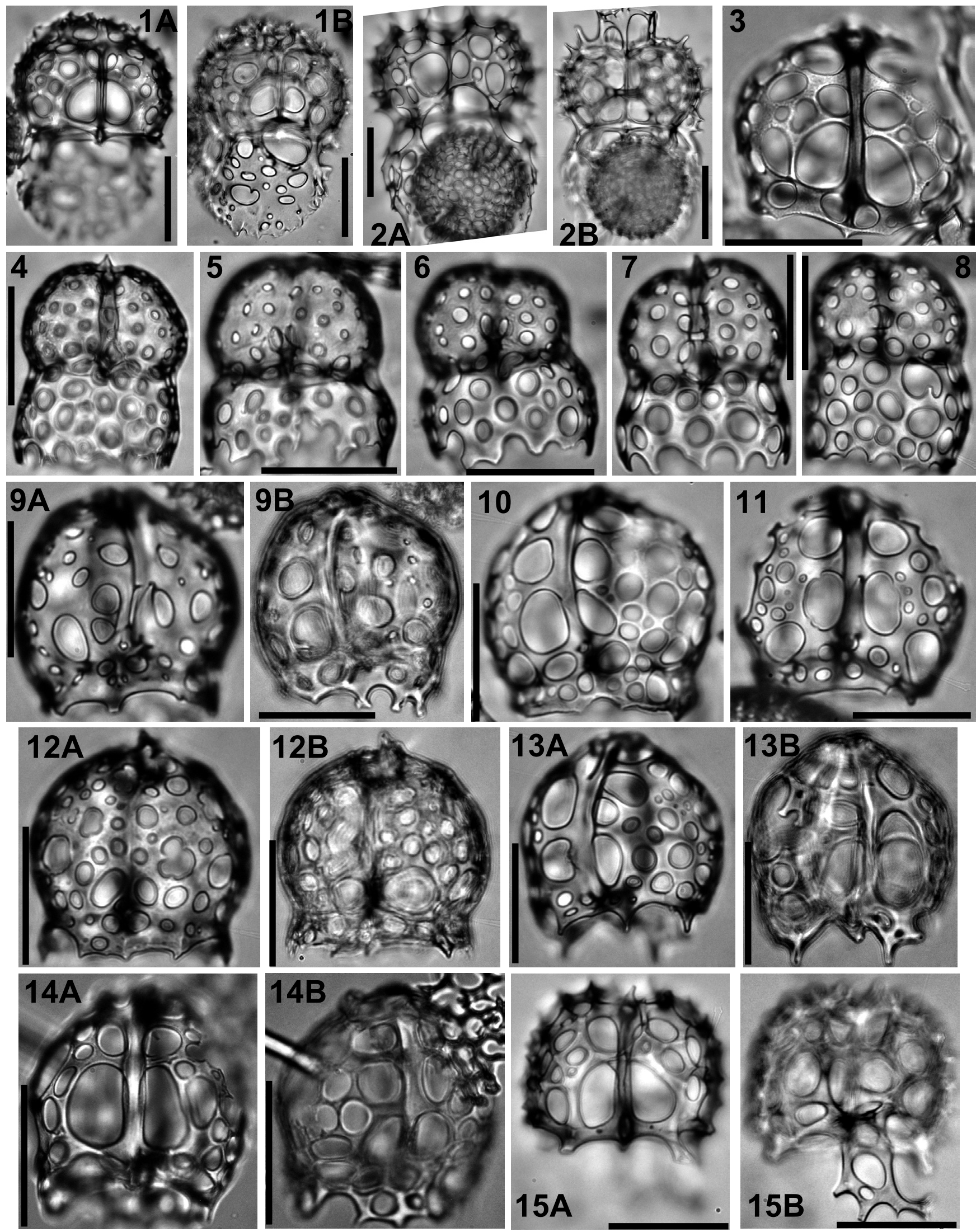

Explanation of Plate 9. figs 1, 15. Tholospyris tautessares n. sp.: 1A, B, sample 120-747A-9H-5, $45-47 \mathrm{~cm}$, holotype; 15A, B, sample 119-744A-11H-3, 60-62 cm. fig. 2A, B. Tholospyris tautessares?, sample 120-747A-9H-8, 45-47 cm. figs 3, 9-11, 13, 14. Ceratospyris clarki n. sp.: 3, sample 119-744A-7H-5, 60-62 cm; 9A, B, sample 120-748B-6H-1, 45-47 cm; 10, sample 120-751 A-15H-CC; 11, sample 120-748B-6H-1, 45-47 cm; 13A, B, sample 120-751A-13H-2, 98-102 cm; 14A, B, sample 119-744A-9H-1, 60-62 cm, holotype. fig. 12A, B. Ceratospyris clarki?, sample 120748B-6H-3, 45-47 cm. figs 4-8. Rhodospyris? morleyi n. sp.: 4, sample 120-748B-7H-4, 45-47 cm; 5, sample 120-748B-8H-2, 45-47 cm, holotype; 6, sample 120-751A-13H-CC; 7, sample 120-751A-13H-CC; 8, sample 120-751A-13H-CC. Scale bars represent $50 \mu \mathrm{m}$. 
differs in its large pores and in lacking a proper constriction between the cephalis and thoracic wall. Dendrospyris bursa Sanfilippo \& Riedel in Sanfilippo et al. (1973) has a considerably larger thorax and a complex apical horn. Finally Gorgospyris rhizopodia Haeckel, 1887 has a cephalic wall that continues above the apex of the sagittal ring. Our new species differs from the forms illustrated as 'De 1' in Goll (1968) and Rhodospyris sp. cf. De 1 group in Petrushevskaya \& Kozlova (1972) and in Ling (1975) in its narrower, open thorax.

Genus Tholospyris Haeckel, 1881 emend. Goll, 1969

Type species. Tholospyris tripodiscus Haeckel, 1887

Tholospyris tautessares $\mathrm{n}$. sp.

(P1. 8, fig. 16A-C, Pl. 9, figs 1A-B, 15A-B; ?P1. 9, fig. 2A-B)

?1969 'T4' Goll: 324, text-fig.1.

?1994 Tholospyris sp. 'T4' Goll; Maharapatra \& Sharma: 164, pl. 3 , figs $15-16$.

Derivation of name. From the Greek letter tau and tessares meaning 'four', tautessares therefore standing for T4 after the codename given to it in Goll (1969).

Diagnosis. Tholospyris with a large pair of sagittal-lattice pores in dorsal view; latticed shell extends below basal ring; constriction at basal ring.

Holotype. Plate 9, figure 1A-B; sample 120-747A-9H-5, 45-47 cm (Middle Miocene); ECO-057, circle 2.

Material. Thirty-five specimens from DSDP Site 278 and ODP Sites 744, 747 and 748 .

Description. Dicyrtid with a cephalis separated into two lobes by a sagittal ring. This separation is marked externally by a moderate constriction. The two segments are separated by a basal ring internally and externally by a constriction. The thorax consists of a thin and smooth latticed wall attached to the basal ring at a few points (including very probably on spines $\mathbf{L} \mathbf{l}$ and $\mathbf{L r}$ at least, see Pl. 8, fig. 16A; Pl. 9, fig. 1B). When more complete (Pl. 8, fig. 16A-C; ?Pl. 9, fig. 2A$\mathrm{B})$, it is shaped like a half-ellipsoid and might possibly be closed.

Above the apex, a short apical cap links spine A resurgence (Pl. 9, figs $1 \mathrm{~A}$ and $2 \mathrm{~B}$ ) and the sides of the cephalic lobes, giving to some specimens a proper hemicircular outline to the cephalis ( $\mathrm{Pl}$. 9, fig. 1A). On the dorsal side (e.g. Pl. 9, fig. 1A), a pair of large sagittallattice pores elongated toward the apex links the basal ring and the sagittal ring. A second smaller pair can be seen above this one. On the ventral side (e.g. Pl. 9, fig. 1B), three medium-sized pairs of sagittal-lattice pores are present. Apart from these pores, the two lobes bear several elliptical pores of various sizes, irregularly arranged, and surrounded by thick, crested bars with raised apices (Pl. 9, figs 2A and 15A). On the thoracic wall, pores are fewer, randomly arranged and elliptical.

Dimensions. Based on four specimens. Total height: 99-167 (140); height of the sagittal ring: 56-72 (61); maximum width of the cephalis: 87-107 (96); long axis of lowermost sagittal-lattice paired pores: $21-30(26)$.

Occurrence. Sporadic from the Cycladophora antiqua to the Eucyrtidium punctatum Zone (Early Miocene).

Remarks. Tholospyris tautessares differs from T. kantiana (Haeckel, 1887), T. baconiana (Haeckel, 1887) and T. newtoniana (Haeckel, 1887) primarily in that the latticed shell above the apex, when present, is considerably reduced. It also differs from Dendrospyris(?) sakaii Sugiyama \& Furutani, 1992 mostly in its peculiar apical structure and in the pattern of the lattice shell below the basal ring. It also differs to some extent from the specimens illustrated as 'T4' in Goll (1969) and T. sp 'T4' Goll in Maharapatra \& Sharma (1994) in the two pairs of sagittal-lattice pores in front view being unequal in size and in the latticed shell below the basal ring lacking a large aperture just below the latter.

\section{Discussion and conclusions}

One striking feature of the Antarctic radiolarian fauna during the Neogene is the richness (in terms of diversity as well as in terms of relative abundance, see Fig. 4; Renaudie \& Lazarus 2013b) in plagiacanthids and more specifically in lophophaenins: 133 species of plagiacanthids (about half of them being lophophaenins) were encountered during our study, including 40 that we described in this series of papers, out of the 490 total species that we observed from the earliest Miocene to the Holocene in this region. It confirms previous observations of high relative diversity of plagiacanthids in (Recent) austral waters by Boltovskoy (1987) and Boltovskoy et al. (2010). These authors show that they are also very abundant in the North Pacific and the tropical Pacific: although the Neogene diversity of plagiacanthids is well documented in the NW Pacific (e.g. Sugiyama 1993; Funakawa 1994 $1995 a, b)$, their tropical diversity as well as their Palaeogene diversity (the group being already present in the late Cretaceous, see e.g. Foreman 1968) is not.

In addition to the underestimated specific diversity of the plagiacanthids, it became obvious during the preparation of this series of papers that their generic taxonomy also needs to be re-examined in detail (see, for instance, the discussions for: Botryopera? daleki Renaudie \& Lazarus, 2013a; Lithomelissa? kozoi Renaudie \& Lazarus, 2013a; Ceratocyrtis? ringisstolla Renaudie \& Lazarus, 2015; Lophophaena? neuma Renaudie \& Lazarus, 2015; or even Spongomelissa? bipatens Renaudie \& Lazarus, 2015).

The problem of the homology of the ring structure of Helotholus? vema Hays, 1965 and, therefore, of this species' relationship with the other lophophaenins (see e.g. Lazarus 1990; Sugiyama 1993) is also still very much open, and with the addition of Antarctissa ballista Renaudie \& Lazarus, 2012 and Botryopera? daleki Renaudie \& Lazarus, 2013a, there are now 14 known species (Helotholus? vema; H.? praevema Weaver, 1983; H.? haysi Lazarus, 1992; H.? warreni (Goll, 1980); Antarctissa ballista; A. cylindrica Petrushevskaya, 1967; A.? whitei Bjørklund, 1976; Botryopera? leptostraca Sugiyama, 1993; B.? daleki; Ceratocyrtis? shimodaensis Sashida \& Kurihara, 1999; Steganocubus incrassatus Funakawa, 1995b; S. irregularis Funakawa, 1995b; S. lipus Sugiyama, 1993; S. subtilis Sugiyama, 1993) bearing such a ring structure, scattered in five different genera (six if we add to the list the plagiacanthin genus Pseudocubus)

Trissocyclid diversity seems also to have been significantly underestimated (we described during this series of papers 11 new species out of the 40 we found in the Southern Ocean Neogene assemblages); however, their generic taxonomy is less problematic thanks to the extensive work of Goll $(1968,1969,1972,1976)$. Theoperidae, in contrast, are recorded in the literature more accurately in comparison to their actual diversity (only eight of our new species are theoperids, even though this family amounts to 84 taxa in this biogeographical province). This, no doubt, reflects the taxonomic knowledge developed from the extensive use of theoperids over several decades in Cenozoic low latitude biostratigraphy (Sanfilippo et al. 1985).

An observation that is perhaps more surprising than the fact that the current representation of the diversity in the radiolarian literature is uneven with respect to families is the fact that some of the new species we described are amongst the most abundant taxa of the Antarctic Neogene (e.g. Antarctissa evanida Renaudie \& Lazarus, 2013a; Arachnocorallium cerebellum Renaudie \& 
Lazarus, 2015; Cystophormis gargantua Renaudie \& Lazarus, 2012; C. petrushevskayae n. sp.; Orodapis hericina Renaudie \& Lazarus, 2012; Pentactinosphaera codonia Renaudie \& Lazarus, 2013a; Trisulcus pinguiculus Renaudie \& Lazarus, 2012) despite the fact that this fauna was studied regularly since the nineteenth century (e.g. Haeckel (1887), Popofsky (1908), Riedel (1958 for Recent faunas), Hays (1965), Chen (1975), Petrushevskaya (1975), Caulet (1977, 1991), Abelmann (1990, 1992), Lazarus (1990, 1992), Lazarus et al. (2005 for fossil forms)). This reflects the influence that biostratigraphic research has both on describing and recording palaeobiodiversity: non-biostratigraphic species are systematically understudied and/or recorded, even if they are common members of the assemblages (Lazarus 2011). Both facts have limited our ability to use the micropalaeontological record of this region for palaeoenvironmental and palaeobiological research. Lastly, although our goal in the re-examination of this material has been to fully document the diversity of species, and we have made major strides towards this goal, the full diversity is still not documented. There are probably a significant number of undescribed species still in groups where the morphology is either very simple, with the potential for iterative evolution of forms (e.g. Actinommidae), or very complex and difficult to understand (e.g. Litheliidae) which will only be resolved by futher study.

\section{Acknowledgements and Funding}

The authors would like to thank Jean-Pierre Caulet and Paulian Dumitrica for their reviews, as well as the scientific editor Taniel Danelian. We would also like to thank the Editor, Alan Lord, and the Production Editor, Sarah Gibbs, for their help during the publication of this series of papers. This work was done in the context of a project financed by DFG (German Science Foundation) grant LA1191/8-1 and -2 .

\section{Scientific editing by Taniel Danelian}

\section{References}

Abelmann, A. 1990. Oligocene to middle Miocene radiolarian stratigraphy of southern high latitudes from Leg 113, Sites 689 and 690, Maud Rise. In: Barker, P.F. et al. (eds) Proceedings of the ODP, Scientific Results, 113. Ocean Drilling Program, College Station, TX, 675-708.

Abelmann, A. 1992. Early to Middle Miocene radiolarian stratigraphy of the Kerguelen Plateau, Leg 120. In: Wise, S.W. Jr., et al. (eds) Proceedings of the ODP, Scientific Results, 120. Ocean Drilling Program, College Station, TX, 757-783.

Abramoff, M.D., Magelhaes, P.J. \& Ram, S.J. 2004. Image Processing with ImageJ. Biophotonics International, 11, 36-42.

Adl, S.M., Simpson, A.G.B. et al. 2005. The new higher level classification of eukaryotes with emphasis on the taxonomy of protists. The Journal of Eukaryotic Microbiology, 52, 399-451.

Bailey, J.W. 1856. Notice of microscopic forms found in the soundings of the Sea of Kamtschatka. American Journal of Science and Arts, 2nd Series, 22, 1-6.

Barron, J.A., Baldauf, J.G. et al. 1991. Biochronologic and magnetochronologic synthesis of Leg 119 sediments from the Kerguelen Plateau and Prydz Bay, Antarctica. In: Barron, J. \& Larsen, B. (eds) Proceedings of the ODP, Scientific Results, 119. Ocean Drilling Program, College Station, TX, 813-847.

Berggren, W.A., Kent, D.V., Swisher, C.C. \& Aubry, M.-P. 1995. A revised Cenozoic geochronology and chronostratigraphy. In: Berggren, W.A., Kent, D.V., Aubry, M.-P. \& Hardenbol, J. (eds) Geochronology, time scales and global stratigraphic correlations: a unified temporal framework for a historical geology. SEPM special publication, 54, 129-212.

Bjørklund, K.R. 1976. Radiolaria from the Norwegian Sea, Leg 38 of the Deep Sea Drilling Project. In: Talwani, M. et al. (eds) Initial Reports of the Deep Sea Drilling Project, 38. US Government Printing Office, Washington, DC, 1101-1168.

Bjørklund, K.R., Itaki, T. \& Dolven, J.K. 2014. Per Theodore Cleve: A short résumé and his radiolarian results from the Swedish Expedition to Spitsbergen in 1898. Journal of Micropalaeontology, 33, 59-93, http://doi. org/10.1144/jmpaleo2012-024

Blueford, J.R. 1982. Miocene actinommid Radiolaria from the Equatorial Pacific. Micropaleontology, 28, 189-213.

Bohaty, S.M., Wise, S.W., Jr., Duncan, R.A., Moore, C.L. \& Wallace, P.J. 2003. Neogene diatom biostratigraphy, tephra stratigraphy, and chronology of ODP Hole 1138A, Kerguelen Plateau. In: Frey, F.A. et al. (eds) Proceedings of the ODP, Scientific Results. Ocean Drilling Program, College Station, TX, 183, 1-53.

Boltovskoy, D. 1987. Sedimentary record of radiolarian biogeography in the equatorial to antarctic western Pacific Ocean. Micropaleontology, 33, 267281.
Boltovskoy, D. 1998. Classification and distribution of South Atlantic recent Polycystine Radiolaria. Palaeontologia Electronica, 1, http://palaeoelectronica.org/content/recent-radiolaria-of-the-south-atlantic

Boltovskoy, D., Kling, S.A., Takahashi, K. \& Bjørklund, K.R. 2010. World atlas of distribution of recent Polycystina (Radiolaria). Palaeontologia Electronica, 13, 1-230.

Borgert, A. 1907. Die Tripyleen Radiolarien der Plankton-Expedition. Concharidae. Ergebnisse der Plankton-Expedition der Humboldt-Stiftung, 3, 195-237.

Campbell, A.S. \& Clark, B.L. 1944. Miocene Radiolarian faunas from Southern California. Geological Society of America, Special Papers, 51, 1-76.

Carnevale, P. 1908. Radiolarie e Silicoflagellati di Bergonzano (Reggio Emilia). Memorie del Reale Istituo Veneto di Scienze, Lettere ed Arti, 28, 1-46.

Caulet, J.-P. 1977. La silice biogène dans les sédiments néogènes et queternaires de l'océan Indien austral. Bulletin de la Société géologique de France, 19, 1021-1022.

Caulet, J.-P. 1979. Les dépôts à radiolaries d'âge Pliocène supérieur à Pleistocène dans l'océan Indien central: Nouvelle zonation biostratigraphique. Mémoires du Museum National d'Histoire Naturelle, Série C, 43, 119-141.

Caulet, J.-P. 1991. Radiolarians from the Kerguelen Plateau, ODP Eg 119. In: Barron, J. \& Larsen, B. (eds) Proceedings of the ODP, Scientific Results. Ocean Drilling Program, College Station, TX, 119, 513-546.

Cavalier-Smith, T. 1998. A revised Six Kingdoms of Life. Biological Reviews, 73, 203-266.

Cavalier-Smith, T. 2002. The phagotrophic origin of eukaryotes and phylogenetic classification of Protozoa. International Journal of Systematic and Evolutionary Microbiology, 52, 297-354.

Chen, P.H. 1975. Antarctic Radiolaria. In: Hayes, D.E. et al. (eds) Initial Reports of the Deep Sea Drilling Project, 28. US Government Printing Office, Washington, DC, 437-513.

Clark, B.S. \& Campbell, A.S. 1945. Radiolaria from the Kreyenhagen Formation near Los Banos, California. Geological Society of America, Memoirs, 10, 1-66.

Cleve, P.T. 1899. Plankton collected by the Swedish Expedition to Spitzbergen in 1898. Kongliga Svenska Vetenskaps-Akademiens Handlingar, 32, 1-51.

Cleve, P.T. 1900. Notes on some Atlantic plankton organisms. Kongliga Svenska Vetenskaps-Akademiens Handlingar, 34, 1-22.

De Wever, P., Sanfilippo, A., Riedel, W.R. \& Gruber, B. 1979. Triassic radiolarians from Greece, Sicily and Turkey. Micropaleontology, 25, 75-110.

De Wever, P., Dumitrica, P., Caulet, J.-P., Nigrini, C. \& Caridroit, M. 2001. Radiolarians in the sedimentary record. Gordon and Breach, Amsterdam, 533.

Dolven, J.K., Bjørklund, K.R. \& Itaki, T. 2014. Jørgensen's polycystine radiolarian slide collection and new species. Journal of Micropalaeontology, 33, 21-58, http://doi.org/10.1144/jmpaleo2012-027

Dreyer, F. 1889. Die Pylombildungen in vergleichend-anatomischer und entwicklungsgeschichtlicher Beziehung bei Radiolarien und bei Protisten überhaupt, nebst System und Beschreibung neuer und der bis jetzt bekannten pylomatischen Spumellarien. Jenaische Zeitschrift für Naturwissenschaft, Jena, 23, 77-214.

Dumitrica, P. 1973. Cretaceous and Quaternary Radiolaria in deep sea sediments from the Northwest Atlantic Ocean and Mediterranean Sea. In: Ryan, W.B.F. et al. (eds) Initial Reports of the Deep Sea Drilling Project, 13. US Government Printing Office, Washington, DC, 829-901.

Dumitrica, P. 1978. Badenian Radiolaria from central Paratethys. In: Brestenska, E. (ed.) Chronostratigraphie und Neostratotypen Miozän der Zentralen Paratethys. Verlag der Slowakischen Academie der Wissenschaften, Bratislava, 6, 231-261.

Dumitrica, P. 1991. Middle Triassic Tripedurnulidae, n. fam. (Radiolaria) from the eastern Carpathians (Romania) and Vicentinian Alps (Italy). Revue de Micropaléontologie, 34, 261-278.

Dumitrica, P. 2013. Cleveiplegma nov. gen., a new generic name for the radiolarian species Rhizoplegma boreale (Cleve, 1899). Revue de Micropaléontologie, 56, 21-25.

Dzinoridze, R.N., Jousé, A.P., Koroleva-Golikova, G.S., Kozlova, G.E., Nagaeva, G.S., Petrushevskaya, M.G. \& Strelnikova, N.I. 1978. Diatom and radiolarian Cenozoic stratigraphy, Norwegian Basin; DSDP Leg 38. In: Talwani, M. et al. (eds) Initial Reports of the Deep Sea Drilling Project, 38. US Government Printing Office, Washington, DC, 289-427.

Ehrenberg, C.G. 1839. Über die Bildung der Kreidefelsen und des Kreidemergels durch unsichtbare Organismen. Königlichen Preußischen Akademie der Wissenschaften zu Berlin, Abhandlungen, Jahre, 1838, 59-147.

Ehrenberg, C.G. 1844. Über 2 neue Lager von Gebirgsmassen aus Infusorien als Meeres-Absatz in Nord-Amerika und eine Vergleichung derselben mit den organischen Kreide-Gebirgen in Europa und Afrika. Monatsberichte der Königlich Preußischen Akademie der Wissenschaften zu Berlin, Jahre, 1844, 57-97.

Ehrenberg, C.G. 1847. Über die mikroskopischen kieselschaligen Polycystinen als mächtige Gebirgsmasse von Barbados und über das Verhältniss der aus mehr als 300 neuen Arten bestehenden ganz eigenthümlichen Formengruppe jener Felsmasse zu den jetzt lebenden Thieren und zur Kreidebildung. Königlichen Preußischen Akademie der Wissenschaften zu Berlin, Bericht, Jahre, 1847, 40-60

Ehrenberg, C.G. 1854. Die systematische Charakteristik der neuen Mikroskopischen Organismen des Tiefen Atlantischen Oceans. Königlichen Preußischen Akademie der Wissenschaften zu Berlin, Bericht, Jahre, 1854, 236-250. 
Ehrenberg, C.G. 1861. Über den Tiefgrund des stillen Oceans zwischen Californien und des Sandwich-Inseln. Königlichen Preußischen Akademie der Wissenschaften zu Berlin, Monatsbericht, Jahre, 1860, 819-833.

Ehrenberg, C.G. 1873. Mikrogeologische Studien über das kleinste Leben der Meeres-Tiefgründe aller Zonen und dessen geologischen Einfluss. Monatsberichte der Königlich Preußischen Akademie der Wissenschaften zu Berlin, Jahre, 1872, 265-322.

Ehrenberg, C.G. 1874. Größere Felsproben des Polycystinen-Mergels von Barbados mit weiteren Erläuterungen. Monatsberichte der Königlich Preußischen Akademie der Wissenschaften zu Berlin, Jahre, 1873, 213-262.

Ehrenberg, C.G. 1876. Fortsetzung der mikrogeologischen Studien als Gesammt übersicht der mikroskopischen Paläontologie gleichartig analysirter Gebirgsarten der Erde, mit specieller Rücksicht auf den Polycystinen-mergel von Barbados. Königlichen Preußischen Akademie der Wissenschaften zu Berlin, Abhandlungen, Jahre, 1875, 1-225.

Foreman, H.P. 1968. Upper Maastrichtian Radiolaria of California. Special Papers in Palaeontology, 3, 1-82.

Foreman, H.P. 1973. Radiolaria of Leg 10 with systematics and ranges for the families Amphipyndacidae, Artostrobiidae, and Theoperidae. In: Worzel, J.L. et al. (eds) Initial Reports of the Deep Sea Drilling Project, 10. US Government Printing Office, Washington, DC, 407-474.

Funakawa, S. 1994. Plagiacanthidae (Radiolaria) from the upper Miocene of eastern Hokkaido, Japan. Transactions and Proceedings of the Palaeontological Society of Japan, New Series, 174, 458-483.

Funakawa, S. 1995a. Intrageneric variation and temporal change in the internal skeletal structure of plagiacanthids (Radiolaria) from Hokkaido, Japan. Transactions and Proceedings of the Palaeontological Society of Japan, New Series, 180, 208-225.

Funakawa, S. 1995b. Lophophaeninae (Radiolaria) from the upper Oligocene to lower Miocene and intrageneric variation in their internal skeletal structures. Journal of Geosciences, Osaka City University, 38, 13-59.

Funakawa, S. 2000. Internal skeletal structures of the Cenozoic genera Gondwanaria, Lipmanella and Lithomelissa (Plagiacanthidae, Nassellaria) and their taxonomy. Micropaleontology, 46, 97-121.

Funakawa, S. \& Nishi, H. 2005. Late middle Eocene to late Oligocene radiolarian biostratigraphy in the Southern Ocean (Maud Rise, ODP Leg 113, Site 689). Marine Micropaleontology, 54, 213-247.

Gersonde, R., Abelmann, A. et al. 1990. Biostratigraphic synthesis of Neogene siliceous microfossils from the Antarctic Ocean, ODP Leg 113 (Weddell Sea). In: Barker, P.F. et al. (eds) Proceedings of the ODP, Scientific Results, 113. Ocean Drilling Program, College Station, TX, 915-936.

Goll, R.M. 1968. Classification and phylogeny of Cenozoic Trissocyclidae (Radiolaria) in the Pacific and Caribbean Basins, Part I. Journal of Paleontology, 42, 1409-1432.

Goll, R.M. 1969. Classification and phylogeny of Cenozoic Trissocyclidae (Radiolaria) in the Pacific and Caribbean Basins, Part II. Journal of Paleontology, 43, 322-339.

Goll, R.M. 1972. Systematics of eight Tholospyris taxa (Trissocyclidae, Radiolaria). Micropaleontology, 18, 443-475.

Goll, R.M. 1976. Morphological intergradation between modern populations of Lophospyris and Phormospyris (Trissocyclidae, Radiolaria). Micropaleontology, 22, 379-418.

Goll, R.M. 1980. Pliocene-Pleistocene radiolarians from the East Pacific Rise and the Galapagos spreading, Deep Sea Drilling Project Leg 54. In: Rosendahl, B.R. et al. (eds) Initial Reports of the Deep Sea Drilling Project, 54. US Government Printing Office, Washington, DC, 425-453.

Goll, R.M. \& Bjørklund, K.R. 1989. A new radiolarian biostratigraphy for the Neogene of the Norwegian Sea: ODP Leg 104. In: Eldholm, O. et al. (eds) Proceedings of the ODP, Scientific Results, 104. Ocean Drilling Program, College Station, TX, 697-737.

Haeckel, E. 1862. Die Radiolarien (Rhizopoda Radiaria). Reimer, Berlin.

Haeckel, E. 1879. Naturliche Schopfungsgeschichte. Reimer, Berlin.

Haeckel, E. 1881. Entwurf eines Radiolarien-Systems auf Grund von Studien der Challenger-Radiolarien. Jenaische Zeitschrift für Naturwissenschaft, 15, 418-472.

Haeckel, E. 1887. Report on the Radiolaria collected by H.M.S. Challenger during the years 1873-1876. Report on the Scientific Results of the voyage of H.M.S. Challenger during the years 1873-1876. Zoology, 18, 1-1803.

Haecker, V. 1907. Altertümliche Spharellarien und Cyrtellarien aus grossen Meerestiefen. Archiv für Protistenkunde, 10, 114-126.

Harwood, D.M., Lazarus, D.B. et al. 1992. Neogene integrated magnetobiostratigraphy of the central Kerguelen Plateau, Leg 120. In: Wise, S.W. Jr., et al. (eds) Proceedings of the ODP, Scientific Results, 120. Ocean Drilling Program, College Station, TX, 1031-1052.

Hays, J.D. 1965. Radiolaria and late Tertiary and Quaternary history of Antarctic seas. In: Llano, G.A. (ed.) Biology of the Antarctic Seas II. Antarctic Research Series, b, 125-184.

Hertwig, R. 1879. Der organismus der Radiolarien. G. Fischer, Jena.

Hollande, A. \& Enjumet, M. 1960. Cytologie, évolution et systématique des Sphaeroïdés (Radiolaires). Archives du Muséum National d'Histoire Naturelle, 7, 1-134.

Jackett, S.-J., Baumgartner, P.O. \& Bandini, A.N. 2008. A new low-latitude late Paleocene-early Eocene radiolarian biozonation based on unitary associations: Applications for accreted terranes. Stratigraphy, 54, 39-62.
Jørgensen, E. 1900. Protophyten und Protozöen in Plankton aus der norwegischen Westküste. Bergens Museums Aarbog, 6, 51-112.

Jørgensen, E. 1905. The Protist plankton and the diatoms in bottom samples. VII. Radiolaria. In: Nordgaard, O., (ed.) Hydrographical and Biological Investigations in Norwegian Fiords. Bergen Museum Skrifter, 114-141.

Kamikuri, S.-I. 2010. New late Neogene radiolarian species from the middle to high latitudes of the North Pacific. Revue de Micropaléontologie, 53, 85-106.

Kling, S.A. 1973. Radiolaria from the eastern North Pacific, Deep Sea Drilling Project, Leg 18. In: Kulm, L.D. et al. (eds) Initial Reports of the Deep Sea Drilling Project, 18. US Government Printing Office, Washington, DC, 617-671.

Kozlova, G.E. 1999. Radiolarii paleogene boreal'noi oblasti Rossii Practicheskoe rykovodstvo po microfayne Rossii, VNIGRI, 9, 1-320.

Lazarus, D.B. 1990. Middle Miocene to Recent radiolarians from the Weddell sea, Antarctica, ODP Leg 113. In: Kennett, J.P. et al. (eds) Proceedings of the $O D P$, Scientific Results, 113. Ocean Drilling Program, College Station, TX, 709-727.

Lazarus, D.B. 1992. Antarctic Neogene radiolarians from the Kerguelen Plateau, Legs 119 and 120. In: Wise, S.W. Jr., et al. (eds) Proceedings of the ODP Scientific Results, 120. Ocean Drilling Program, College Station, TX, 785-809.

Lazarus, D.B. 2006. The Micropaleontological Reference Center Network. Scientific Drilling, 3, 46-49.

Lazarus, D. 2011. The deep-sea microfossil record of macroevolutionary change in plankton and its study. In: Smith, A. \& McGowan, A. (eds) Comparing the Geological and Fossil Records: Implications for Biodiversity Studies. Geological Society, London, Special Publications, 358, 141-166, http://doi. org/10.1144/SP358.10

Lazarus, D.B. \& Pallant, A. 1989. Oligocene and Neogene radiolarians from the Labrador Sea, ODP Leg 105. In: Srivastava, S.P. et al. (eds) Proceedings of the ODP, Scientific Results, 105. Ocean Drilling Program, College Station, TX, 349-380.

Lazarus, D.B., Faust, K. \& Popova-Goll, I. 2005. New species of prunoid radiolarians from the Antarctic Neogene. Journal of Micropalaeontology, 24, 97-121, http://doi.org/10.1144/jm.24.2.97

Lees, J.M. 2010. GEOmap: Topographic and Geologic Mapping. R package version 1.5-4.

Ling, H.Y. 1975. Radiolaria: Leg 31 of the deep sea drilling project. In: Karig, D.E. et al. (eds) Initial Reports of the Deep Sea Drilling Project, 31. US Government Printing Office, Washington, DC, 703-761.

Lipman, R.Kh. 1972. Novye eotsenovyie radiolyarii Turchayskogo prochiba i Severnogo Priaraiya. Novyie Vyidyi Drevnyikh Rastenyyi $i$ Bespozvonochnyikh SSSR, Nauka, Moskva, Akademiya Nauk SSSR, Nauchnyiy Sovet po Probleme, 42-56.

Maharapatra, A.K. \& Sharma, V. 1994. Trissocyclid Radiolaria from the late Early Miocene sequences of Colebrook, North Passage and Great Nicobar Islands, northeast Indian Ocean. Micropaleontology, 40, 157-168.

Moore, T.C., Jr. 1972. Mid-Tertiary evolution of the radiolarian genus Calocycletta. Micropaleontology, 18, 144-152.

Moore, T.C., Jr. 1973. Method of randomly distributing grains for microscope examination. Journal of Sedimentary Petrology, 43, 904-906.

Motoyama, I. 1996. Late Neogene radiolarian biostratigraphy in the subarctic Northwest Pacific. Micropaleontology, 42, 221-262.

Müller, J. 1858. Über die Thalassicollen, Polycystinen und Acanthometren des Mittelmeeres. Königlichen Preußischen Akademie der Wissenschaften zu Berlin, Abhandlungen, Jahre, 1858, 1-62.

Nakaseko, K. 1963. Neogene Cyrtoidea (Radiolaria) from the Isozaki Formation in Ibaraki Prefecture, Japan. Science Reports, College of General Education, Osaka University, 12, 165-198.

Nakaseko, K. \& Nishimura, A. 1974. Miocene radiolarian fossils of the Oki Islands in Shimane Prefecture, Japan. Science Reports, College of General Education, Osaka University, 23, 45-73.

Nakaseko, K., Nagata, K. \& Nishimura, A. 1983. Pentactinosphaera hokurikuensis (Nakaseko): A revised Early Miocene Radiolaria. Science Reports, College of General Education, Osaka University, 32, 31-37.

Nigrini, C. 1968. Radiolaria from eastern tropical Pacific Sediments Micropaleontology, 14, 51-63.

Nigrini, C. 1971. Radiolarian zones in the Quaternary of the equatorial Pacific Ocean. In: Funnell, B.M. \& Riedel, W.R. (eds) The Micropaleontology of the Oceans. Cambridge University Press, Cambridge, 443-461.

Nigrini, C. 1977. Tropical Cenozoic Artostrobiidae (Radiolaria). Micropaleontology, 23, 241-269.

Nigrini, C. \& Caulet, J.-P. 1988. The genus Anthocyrtidium (Radiolaria) from the tropical late Neogene of the Indian and Pacific Oceans. Micropaleontology, 34, 341-360.

Nigrini, C. \& Lombari, G. 1984. A guide to Miocene Radiolaria. Cushman Foundation for Foraminiferal Research, Special Publication, 22.

Nishimura, A. 1992. Paleocene radiolarian biostratigraphy in the northwest Atlantic at Site 384, Leg 43, of the Deep Sea Drilling Project. Micropaleontology, 38, 317-362.

Nishimura, A. \& Yamauchi, M. 1984. Radiolarians from the Nankai Trough in the Northwest Pacific. News of Osaka Micropaleontologists, Special Volume, 6, 1-148.

Nishimura, H. 1990. Taxonomic study on Cenozoic Nassellaria (Radiolaria). Science Report of the Institute of Geosciences, University of Tsukuba, section $B, \mathbf{1 1}, 69-172$ 
O’Connor, B. 1997. Lower Miocene Radiolaria from Te Kopua Point, Kaipara Harbour, New Zealand. Micropaleontology, 43, 101-128.

Ogane, K., Suzuki, N., Aita, Y., Sakai, T. \& Lazarus, D. 2009. Ehrenberg's radiolarian collections from Barbados. In: Tanimura, Y. \& Aita, Y. (eds) Joint Haeckel and Ehrenberg Project: Reexamination of the Haeckel and Ehrenberg Microfossil Collection as a historical and scientific legacy. National Museum of Nature and Science Monographs, Tokyo, 40 97-106

Petrushevskaya, M.G. 1965. Osobennosti i konstruktsii skeleta radiolyarii Botryoidae (otr. Nassellaria). Trudy Zoologicheskogo Instituta, 35, 79-118.

Petrushevskaya, M.G. 1967. Radiolaryii otryadov Spumellaria i Nasselaria antarkticheskoi oblasti. Issledovaniya Fauny Morei, 4, 2-186.

Petrushevskaya, M.G. 1968. Gomologii v skeletakh radiolyarii Nassellaria. 1. Osnovnye dugi v semeistve Cyrtoidea. Zoologicheskii Zhurnal, 47, 12961310 .

Petrushevskaya, M.G. 1971. Radiolyarii Nassellaria v planktone mirovogo okeana. Issledovaniya Fauny Morei, 9, 1-294.

Petrushevskaya, M.G. 1975. Cenozoic radiolarians of the Antarctic, Leg 29, Deep Sea Drilling Project. In: Kennett, J.P. et al. (eds) Initial Reports of the Deep Sea Drilling Project, 29. US Government Printing Office, Washington, DC, 541-676.

Petrushevskaya, M.G. 1981. Radiolyarii otryada Nassellaria mirovogo okeana Opredeliteli po faune S.S.S.R., Izdavemye Zoologitcheskyim Institutom Akademyi Nauk S.S.S.R., 128

Petrushevskaya, M.G. \& Kozlova, G.E. 1972. Radiolaria: Leg 14, Deep Sea Drilling Project. In: Hayes, D.E. et al. (eds) Initial Reports of the Deep Sea Drilling Project, 14. US Government Printing Office, Washington, DC, 495-648.

Popofsky, A. 1908. Die Radiolarien der Antarktis. Deutsche SüdpolarExpedition 1901-1903, 10, 183-305.

Popofsky, A. 1912. Die Sphaerellarien des Warmwassergebietes. Deutsche Südpolar-Expedition 1901-1903, 13, 73-159.

Popofsky, A. 1913. Die Nassellarien des Warmwassergebietes. Deutsche Südpolar-Expedition 1901-1903, 14, 217-416.

Renaudie, J. \& Lazarus, D.B. 2012. New species of Neogene radiolarians from the Southern Ocean. Journal of Micropalaeontology, 31, 29-52, http://doi. org/10.1144/0262-821X10-026

Renaudie, J. \& Lazarus, D.B. $2013 a$. New species of Neogene radiolarians from the Southern Ocean - Part II. Journal of Micropalaeontology, 32, 59-86, http://doi.org/10.1144/jmpaleo2011-025

Renaudie, J. \& Lazarus, D.B. 2013b. On the accuracy of paleodiversity reconstructions: A case study in Antarctic radiolarians. Paleobiology, 39, 491-509.

Renaudie, J. \& Lazarus, D.B. 2015. New species of Neogene radiolarians from the Southern Ocean - Part III. Journal of Micropalaeontology, 34, 181-209, http://doi.org/10.1144/jmpaleo2013-034

Reynolds, R.A. 1980. Radiolarians from the western north Pacific, Leg 57 , Deep Sea Drilling Project. In: Langseth, M. et al. (eds) Initial Reports of the Deep Sea Drilling Project, 56. US Government Printing Office, Washington, DC, 735-769.

Riedel, W.R. 1958. Radiolaria in Antarctic sediments. Reports of the B.A.N.Z. Antarctic Research Expedition. Series B, 6, 218-254.

Riedel, W.R. 1967. Some new families of Radiolaria. Geological Society of London, Proceedings, 1640, 148-149.

Riedel, W.R. \& Sanfilippo, A. 1971. Cenozoic Radiolaria from the Western Tropical Pacific, Leg 7. In: Winterer, E.L. et al. (eds) Initial Reports of the Deep Sea Drilling Project, 7. US Government Printing Office, Washington, DC, 1529-1672.

Sakai, T. 1980. Radiolarians from Sites 434, 435, and 436, Northwest Pacific, Leg 56, Deep Sea Drilling Project. In: Langseth, M. et al. (eds) Initial Reports of the Deep Sea Drilling Project, 56. US Government Printing Office, Washington, DC, 695-733.
Sanfilippo, A. \& Riedel, W.R. 1973. Cenozoic Radiolaria (exclusive of Theoperids, Artostrobiids and Amphipyndacids) from the Gulf of Mexico, DSDP Leg 10. In: Worzel, J.L. et al. (eds) Initial Reports of the Deep Sea Drilling Project, 10. US Government Printing Office, Washington, DC, 475-611.

Sanfilippo, A. \& Riedel, W.R. 1980. A revised generic and suprageneric classification of the Artiscins (Radiolaria). Journal of Paleontology, 54, 10081011.

Sanfilippo, A. \& Riedel, W.R. 1992. The origin and evolution of Pterocorythidae (Radiolaria): A Cenozoic phylogenetic study. Micropaleontology, 38, 1-36.

Sanfilippo, A., Burckle, L.H., Martini, E. \& Riedel, W.R. 1973. Radiolarians, diatoms, silicoflagellates and calcareous nannofossils in the Mediterranean Neogene. Micropaleontology, 19, 209-234.

Sanfilippo, A., Westberg-Smith, M.J. \& Riedel, W.R. 1985. Cenozoic Radiolaria. In: Bolli, H.M., Saunders, J.B. \& Perch-Nielsen, K. (eds) Plankton Stratigraphy. Cambridge University Press, Cambridge, 631-712.

Sashida, K. \& Kurihara, T. 1999. Recent radiolarian faunas in the surface water off the coast of Shimoda, Izu Peninsula, Japan. Science Report of the Institute of Geosciences, University of Tsukuba, section B, 20, 115-144.

Seguenza, G. 1880. Le formazioni terziare nella provincia di Reggio (Calabria). Atti della Real Accademia dei Lincei, Serie Terza, Memorie della classe di Scienze Fisiche, Matematiche e Naturali, 6, 1-446.

Spencer-Cervato, C. 1999. The Cenozoic deep-sea microfossil record: Explorations of the DSDP/ODP sample set using the Neptune database. Palaeontologia electronica, 2, 1-270.

Stöhr, E. 1880. Die Radiolarienfauna der Tripoli von Grotte, Provinz Girgenti in Sicilien. Palaeontographica, 26, 69-124.

Streeter, L.S. 1988. Two species (one new) of Plio-Pleistocene Radiolaria from the central equatorial Indian Ocean. Micropaleontology, 34, 63-66.

Sugiyama, K. 1992. New spumellarians (Radiolaria) from the lower Miocene Toyohama Formation, Morozaki Group, central Japan. Bulletin of the Mizunami Fossil Museum, 19, 193-197.

Sugiyama, K. 1993. Skeletal structures of lower and middle Miocene lophophaenids (Radiolaria) from central Japan. Transactions and Proceedings of the Palaeontological society of Japan, New Series, 169, 44-72.

Sugiyama, K. \& Furutani, H. 1992. Middle Miocene radiolarians from the Oidawara Formation, Mizunami Group, Gifu Prefecture, central Japan. Bulletin of the Mizunami Fossil Museum, Dr. Junji Itoigawa memorial volume, 19, 199-213.

Suzuki, N., Ogane, K. \& Chiba, K. 2009a. Middle to Late Eocene polycystine radiolarians from the Site 1172, leg 189, southwest Pacific. News of Osaka Micropaleontologists, Special Volume, 14, 239-296.

Suzuki, N., Ogane, K., Aita, Y., Sakai, T. \& Lazarus, D. 2009b. Reexamination of Ehrenberg's Neogene Radiolarian collections and its impact on taxonomic stability. In: Tanimura, Y. \& Aita, Y. (eds) Joint Haeckel and Ehrenberg Project: Reexamination of the Haeckel and Ehrenberg Microfossil Collection as a historical and scientific legacy. National Museum of Nature and Science Monographs, Tokyo, 40, 87-96.

Vinassa de Regny, P.E. 1900. Radiolari Miocenici Italiani. Memorie della Reale Accademia delle scienze dell'Istituto di Bologna, 5, 227-257.

Vishnevskaya, V.S. 2006. New species of the Family Heliodiscidae Haeckel (Radiolaria). Paleontological Journal, 40, 134-142.

Weaver, F.M. 1976. Antarctic Radiolaria from the southeast Pacific Basin, Deep Sea Drilling Project, Leg 35. In: Hollister, C.D. et al. (eds) Initial Reports of the Deep Sea Drilling Project, 35. US Government Printing Office, Washington, DC, 569-603.

Weaver, F.M. 1983. Cenozoic radiolarians from the Southwest Atlantic, Falkland Plateau region, Deep Sea Drilling Project, Leg 71. In: Ludwig, W.J. et al. (eds) Initial Reports of the Deep Sea Drilling Project, 71. US Government Printing Office, Washington, DC, 667-686. 